\title{
The long-horned caddisfly genus Oecetis (Trichoptera: Leptoceridae) in Australia: two new species groups and 17 new species
}

\author{
Alice Wells
}

Australian Biological Resources Study, Department of the Environment and Heritage, Canberra, ACT 2600, Australia (alice.wells@deh.gov.au)

\begin{abstract}
Wells, A. 2004. The long-horned caddisfly genus Oecetis (Trichoptera: Leptoceridae) in Australia: two new species groups and 17 new species. Memoirs of Museum Victoria 61(1): 85-110.

Among Australian caddisflies (Insecta: Trichoptera), the leptocerid genus Oecetis McLachlan is one of the most widespread and diverse genera. This paper brings to 53 the number of described species recorded for Australia, and at least a further 15 to 20 species remain to be described. Here 17 newly described species are assigned with 12 others to an informal laustra-group, defined by having the phallus simple and lacking parameres. Three other newly described species are placed in another informal group, the longiterga-group, based on the broad form of the forewing and strongly pronounced venation. Distributions are plotted for most species, new records extending distributions considerably; of the 29 laustragroup species included here, 15 are known in Australia only from the north of the continent. Keys are provided to the informal species-groups recognised for Australia, and to males of the laustra- and longiterga-groups.
\end{abstract}

Keywords

Taxonomy, Trichoptera, Leptoceridae, Oecetis, new species, Australia

\section{Contents}

Introduction

Key to males of Oecetis species groups in Australia

Key to males of the Oecetis laustra-group in Australia

Key to males of the Oecetis longiterga-group in Australia 89

Species of the laustra-group

Oecetis laustra Mosely, 1953

Oecetis pseudolaustra sp. nov.

Oecetis atarpa Mosely, 1953

Oecetis scirpicula Neboiss, 1977

Oecetis inscripta Kimmins, 1953

Oecetis brevidentata sp. nov.

Oecetis asmanista Mosely, 1953

Oecetis minasata Mosely, 1953

Oecetis erskinensis sp. nov.

Oecetis aeoloptera Kimmins, 1953

Oecetis multipunctata Ulmer, 1916

Oecetis cracenta sp. nov.

Oecetis parka Mosely, 1953

Oecetis arcada Mosely, 1953

Oecetis cymula Neboiss, 1982

Oecetis paracymula $\mathrm{sp}$. nov.

Oecetis spicata sp. nov.

Oecetis crena sp. nov.

Oecetis quadrata sp. nov.

Oecetis dilata sp. nov.
Oecetis koobarra sp. nov.

Oecetis falcata sp. nov. 101

Oecetis terrania sp. nov. 101

Oecetis papposa sp. nov. $\quad 101$

Oecetis curta sp. nov. 103

Oecetis aduncata sp. nov. 103

Oecetis ornata Kimmins, 1962

Oecetis cepaforma sp. nov. 104

Oecetis dostinei sp. nov. 105

Species of the longiterga-group 105

Oecetis digitata sp. nov.

Oecetis ancala sp. nov. $\quad 106$

Oecetis crosslandi sp. nov. 107

Acknowledgements 107

References 110

\section{Introduction}

Oecetis McLachlan, 1877 (Leptoceridae), a cosmopolitan genus of long-horned caddisflies, is one of several genera of Trichoptera represented Australia-wide, occurring even in the arid inland. Light trap samples of caddisflies in Australia seldom fail to include several species and often adults and immatures of some species are abundant. Adults of most Australian species are rather nondescript in appearance, although some have distinctive wing markings, and many members of one group have patches of scales on the forewing. 
On the basis of features of wing venation and male genitalia, however, five distinct groups can be recognised among Australian species of Oecetis. Two of these were dealt with recently. Males of the reticulata-group (Neboiss, 1989), have an amour-like, sculptured dorsal plate formed by the extension of abdominal tergite VIII over the terminal segments of the abdomen. In the complexa-group (Wells, 2000), males are characterised by external spiny processes or parameres associated with the phallus, and forewing fork 1 with a footstalk. Here, two further groups are recognised, the laustra- and longitergagroups. A fifth group, the pechana-group, will be dealt with in a subsequent paper.

The laustra-group is distinguished by having the phallus very simple, lacking parameres or spines of any kind (Fig. 3). This group, its name taken from a widespread and common Australian species, comprises 29 species, 17 of them newly described. Most of these have the forewing with a distinct footstalk on fork 1, the feature upon which Chen (1992), in his unpublished revision, based a subgroup in one of his subgenera. Several species, however, have the footstalk very short (indistinct), and several have fork 1 sessile.

The longiterga-group, named for a New Guinea species, share a wing form atypical in the Australian fauna (Figs 91, 94), with pronounced veins and fork 1 sessile. Three new Australian species are included: $O$. crosslandi sp. nov., $O$. ancala sp. nov. and $O$. digitata sp. nov. Another unpublished New Guinean species is known that shares this wing form (Chen, 1992: fig. 4.3).

Species of the laustra-group vary in tibial spur counts: spur formulae may be $0,2,2$ or $1,2,2$. A count of 2, 2, 2 for $O$. scirpicula Neboiss, 1977 was reported, but has not been verified in material checked in this study. Variation is seen, too, in length of wing setae, with some species having long downy setae along veins while others have the vestiture uniformly short over the wing laminae, although always longer on the distal margins. Some wings are uniformly fuscous, yet others show distinctive patterns, with darker brown to black markings produced by differences in wing membrane colour, emphasised by the colour of the setae. Wing shape varies. Forewings are generally slender, having length to width ratios close to 4 , but are broader in some species. The position of transverse veins in the forewing, especially the posterior anastomosis (Fig. 1, following terminology of Ruiter, 2000, after Schmid, 1980), varies across the group. The crossveins are denoted $\mathrm{t} 1$ for that closing discoidal cell, $\mathrm{t} 2$ for $\mathrm{r}-\mathrm{m}$, and $\mathrm{t} 3$ for the vein closing the thyridial cell. In some species, $\mathrm{t} 1, \mathrm{t} 2$, and $\mathrm{t} 3$ are more or less contiguous, or linear - as in O. scirpicula, in others no two transverse veins are aligned - as in O. multipunctata Ulmer, 1916 and $O$. parka Mosely, 1953. Variation within some species is apparent. Thus, in $O$. laustra the posterior anastomosis is linear in some populations, while the crossveins are slightly out of alignment in others. None of the laustra-group species has wing-scales such as occur in most of the pechana-group.

Assignment of males to the five Oecetis species groups using the key provided here is reasonably straightforward. Using the key to $O$. laustra-group species, however, may be difficult. Where possible, wing features are used for differentiation and several species are readily identified by their characteristic wing markings. For others, the often more cryptic genitalic features must be used. It is recommended that, when identifications are being made, close attention be given to the illustrations provided and to notes on variation within species.

Extensive collections in Museum Victoria (NMV), Australian National Insect Collection (ANIC) and Northern Territory Museum and Art Galleries (NTM) were available for this study; other depositories of types or new material are The Natural History Museum, London (BMNH), Queensland Museum (QM) and Waite Agricultural Research Institute (WARI). For all established species, only a diagnosis, illustrations and new distribution data are given. For the more commonly collected species, only distribution maps are given the detailed locality data are not included here, or are included for type material only; these data are available from the author or from NMV. Members of the laustra-group occur in all Australian states and territories, and tend to be more or less peripherally distributed on the mainland; several species are found in Tasmania and one is described from Lord Howe Island. Some species appear to be localised, and others to have disjunct distributions (see Table 1); similar patterns were reported for complexa-group species (Wells, 2000). Fifteen laustra-group species are known only from northern Australia, and the richest diversity — 16 species — is recorded for Queensland (see Table 1), with most records being from along the eastern seaboard; four of these species have been collected from northern Queensland only, and one is known from Queensland and New Guinea. Few species in this group are recorded for south-western Western Australia or South Australia. Two species assigned to the longiterga-group are recorded only from northern Australia; the third is widespread - collected from northern Western Australia, the north of the NT, south-eastern Qld, eastern NSW and south-central Victoria.

As for species of the complexa-group, few females can be associated with males with certainty. Thus, new species are diagnosed on the basis of males only. Several observations on biology are pertinent, some deduced from label data. For example, locality data for $O$. laustra include a large number of lacustrine sites. Larvae of this species build their case from portions cut from stems of aquatic macrophytes and live amongst and on these plants (Wells, 1991; St Clair, 1994); the cases are very light and would readily be swept free of the substratum by currents. In contrast, it appears from label data that O. arcada Mosely, 1953, O. asmanista Mosely, 1953 and O. cymula Neboiss, 1982 are probably adapted to swiftly flowing waters. I have found the sand grain-cased larvae of $O$. digitata sp. nov. in sand in the direct flow of water under small rocky falls, and those of $O$. koobarra sp. nov. amongst sand on ledges in the bedrock of small permanent creeks that have moderate flow, but are subject to occasional spates. Larvae and pupae of $O$. erskinensis sp. nov., from Lord Howe Island, were collected from crevices, ridges and ledges in the main flow of a small steam. Like many other species, $O$. brevidentata $\mathrm{sp}$. nov. constructs sand-grain cases and is found associated with boulders and cobbles in sand- or cobblebased creeks or rivers. 
Table 1. Oecetis laustra-group species clustered according to state/territory of occurrence with the exception that a distinction is made between the north-west and south-west of Western Australia, and Lord Howe Island is included (LHI). Arrangement designed to emphasis commonalities between parts of Australia. (Abbreviations: Qld, Queensland; NSW, New South Wales; Vic., Victoria; Tas., Tasmania; SA, South Australia; SWWA south-western Western Australia; NWWA, north-western Western Australia; NT, Northern Territory; LHI, Lord Howe Island).

\begin{tabular}{|c|c|c|c|c|c|c|c|c|c|}
\hline SPECIES & $\begin{array}{l}\text { SW } \\
\text { WA }\end{array}$ & $\begin{array}{l}\text { NW } \\
\text { WA }\end{array}$ & NT & Qld & NSW & Vic. & Tas. & SA & L H I \\
\hline Oecetis erskinensis sp. nov. & & & & & & & & & + \\
\hline Oecetis scirpicula Neboiss, 1977 & & & & & & & + & & \\
\hline Oecetis crena sp. nov. & & & & & & + & & & \\
\hline Oecetis arcada Mosely, 1953 & & & & & & + & + & & \\
\hline Oecetis asmanista Mosely, 1953 & & & & & & + & + & & \\
\hline Oecetis paracymula sp. nov. & & & & & + & & & & \\
\hline Oecetis terania sp. nov. & & & & & + & & & & \\
\hline Oecetis minasata Mosely, 1953 & & & & & + & + & + & & \\
\hline Oecetis parka Mosely, 1953 & & & & + & + & + & & & \\
\hline Oecetis aduncata sp. nov. & & & & + & + & + & & & \\
\hline Oecetis curta sp. nov. & & & & + & + & & & & \\
\hline Oecetis inscripta Kimmins, 1953 & & & & + & + & + & + & + & \\
\hline Oecetis laustra Mosely, 1953 & + & + & + & + & + & + & + & + & \\
\hline Oecetis atarpa Mosely, 1953 & + & + & & + & + & + & + & + & \\
\hline Oecetis aeoloptera Kimmins, 1953 & & & + & + & + & + & & & \\
\hline Oecetis dostinei sp. nov. & & & + & + & & & & & \\
\hline Oecetis dilata sp. nov. & & + & + & + & & & & & \\
\hline Oecetis spicata sp. nov. & & + & + & + & & & & & \\
\hline Oecetis cepaforma sp. nov. & & + & + & + & & & & & \\
\hline Oecetis papposa sp. nov. & & + & + & & & & & & \\
\hline Oecetis cracenta sp. nov. & & + & + & & & & & & \\
\hline Oecetis brevidentata $\mathrm{sp}$. nov. & & & + & & & & & & \\
\hline Oecetis koobarra sp. nov. & & & + & & & & & & \\
\hline Oecetis pseudolaustra sp. nov. & & & & + & & & & & \\
\hline Oecetis falcata sp. nov. & & & & + & & & & & \\
\hline Oecetis quadrata sp. nov. & & & & + & & & & & \\
\hline Oecetis multipunctata Ulmer, 1916 & & & & + & & & & & \\
\hline Oecetis ornata Kimmins, 1962 & & & & + & & & & & \\
\hline Oecetis cymula Neboiss, 1982 & + & & & & & & & & \\
\hline Total species & 3 & 7 & 10 & 16 & 10 & 10 & 7 & 3 & \\
\hline
\end{tabular}

Generally, larval morphology of Oecetis species is remarkably uniform, a major difference being colour patterns on the head and pro- and mesonota, and occasional differences are apparent in ventral head and thoracic sternal sclerites, and in setation (Floyd, 1995; St Clair, 2000). However, mandibles of at least one laustra-group species, $O$. brevidentata sp. nov., are short and stout (Wells, 1991), suggesting a different diet from that of most species. The more characteristic mandible form is slender and sharply pointed.

\section{Key to males of Oecetis species groups in Australia}

1. Abdominal tergite VIII sculptured, expanded and extended distally, forming shield over terminal abdominal segments and genitalia $\ldots \ldots \ldots \ldots \ldots \ldots \ldots$ . . . . . . . . . reticulata-group (see Neboiss, 1989)

- Abdominal tergite VIII unmodified ... . . . . . . . . 2

2. Wings with veins strongly pronounced, fork 1 without a footstalk (sessile) (Figs 91, 94) . . . . . longiterga-group
- Wings with veins normal, not particularly well pronounced, fork 1 with or without footstalk (Figs 1, 30, 53)

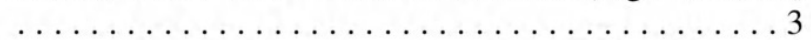

3. Phallus simple, lacking parameres (Figs 3, 38, 72) .... ................. laustra-group (see below)

- Phallus with one or more internal or external parameres or spines $\ldots \ldots \ldots \ldots \ldots \ldots \ldots \ldots \ldots \ldots \ldots \ldots \ldots \ldots \ldots \ldots$

4. Forewing fork 1 sessile, wing lamina often bearing patches of scales (androconia); phallus usually with a single internal paramere or spine $\ldots . .$. pechana-group

- Forewing fork 1 stalked, wing never bearing patches of scales; phallus with one or more external parameres .... ............ complexa-group (see Wells, 2001)

\section{Key to males of the Oecetis laustra-group in Australia}

1. Forewing with distinct footstalk on fork 1 (Fig. 1) . . . 2

- Forewing with fork 1 sessile (Figs 80, 87, 88), or very

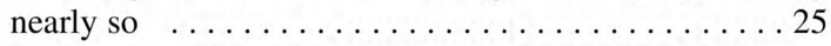


2. In hind wing, $\mathrm{M}$ unbranched (Fig. 73); in male genitalia in lateral view, inferior appendages about same width basally and apically, constricted mesially (Fig. 72) ...O. papposa

- In hind wing, $\mathrm{M}$ branched; male genitalia not as above .3

3. In hind wing, $\mathrm{Cu} 1$ and $\mathrm{Cu} 2$ arise at crossvein $\mathrm{M}-\mathrm{Cu}$ (Fig. 53) .................. quadrata

- In hind wing, $\mathrm{Cu} 1$ and $\mathrm{Cu} 2$ arise distal to crossvein $\mathrm{M}-\mathrm{Cu}$

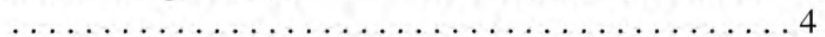

4. In forewing, at least 2 crossveins contiguous (linear), or nearly so, in posterior anastomosis (Figs 10, 12) . . . 5

- In forewing, crossveins of posterior anastomosis all

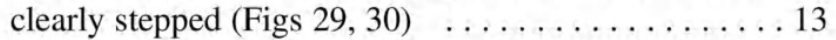

5. Forewing with distinctive dark lines marking parts of veins, including diagonal mark linking $\mathrm{t} 1, \mathrm{t} 2, \mathrm{t} 3$ (Fig. 12)

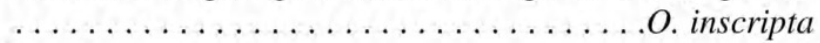

- Forewing not as above $\ldots \ldots \ldots \ldots \ldots \ldots \ldots$

6. In genitalia, inferior appendages in lateral view swollen basally, distally reduced to at least one-third basal width and strongly curved dorsad $\ldots \ldots \ldots \ldots \ldots \ldots$

- In genitalia, inferior appendages in lateral view not as

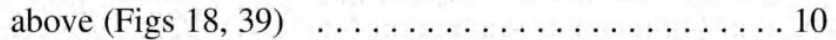

7 In genitalia, in ventral view, inferior appendages tapered gradually towards apex, mesial margin slightly dentate or with a single sharp mesial hook (Fig. 2) $\ldots \ldots \ldots \ldots 8$

- In genitalia, in ventral view, inferior appendages sharply excavated at about one-third length, distally slender, mesial margin smooth (Figs 8,26$) \ldots \ldots \ldots$

8. In genitalia, in ventral view, inferior appendages with a small mesial tooth (Fig. 2) $\ldots \ldots \ldots \ldots \ldots$. laustra

- In genitalia, in ventral view, inferior appendages with a sharp anteriorly directed mesial hook (Fig. 4) . . . . . . .

9 Forewing with dark membrane marking posterior anastomosis; genitalia in lateral view with peg-like process ventral to preanal appendages (Fig. 9) ..... O. atarpa

- Forewing without dark markings at posterior anastomosis (Fig.10); without peg-like process ventral to preanal appendages (Fig. 11) . . . . . . . . . . scirpicula

10. In forewing $\mathrm{t} 3$ well proximal to $\mathrm{t} 1$ and $\mathrm{t} 2$, with $\mathrm{M} 3+4$ arising distal to $\mathrm{t} 3$; wing lamina patterned with dark marking on crossveins $\mathrm{t} 1, \mathrm{t} 2$ and $\mathrm{M}$ forming a short dark distal

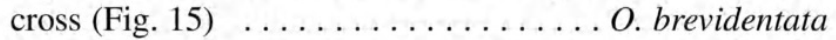

- In forewing $\mathrm{t} 3$ only slightly proximal to $\mathrm{t} 1$ and $\mathrm{t} 2$, with $\mathrm{M} 3+4$ arising at $\mathrm{t} 3$; wing lamina mottled, without distinct

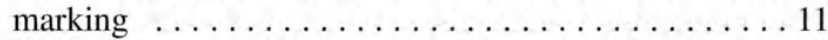

11. In genitalia in ventral view, inferior appendages broad in basal two-thirds, mesial margin rounded then abruptly constricted, curved inwards towards apices, not sharply angled (Fig. 19); tergite X slim, digitiform ...... O. asmanista

- In genitalia in ventral view, inferior appendages broadbased with meso-ventral angle slightly lobed, mesial margin strongly constricted to form a narrow lobe laterodistally, with apex sharply angled inwards (Figs 21, 24); tergite $\mathrm{X}$ a broad membrane . . . . . . . . . . 12

12. In genitalia in ventral view, phallus with apex sharply delineated and deeply V-shaped (Fig. 24) . .O. erskinensis

- In genitalia in ventral view, phallus with apex rounded, very shallowly cleft (Fig. 21) . . . . . . . O. minasata
13. In forewing, $\mathrm{t} 1$ more distal than $\mathrm{t} 2$ or $\mathrm{t} 3$ (Figs 64, 73) .14

— In forewing, $\mathrm{t} 2$ more distal than $\mathrm{t} 1$ or $\mathrm{t} 3$ (Fig. 30) . . .17

14. Male genitalia with prominent, unequal sclerotised spines dorsally (Figs 65-67) . . . . . . . . . . . falcata

— Male genitalia without any sclerotised spines (Figs 60, 62)

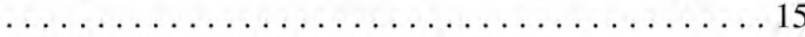

15. Forewing fork 1 and its footstalk about equal length; on forewing a zig-zag pattern marks posterior anastomosis (Fig. 63) ................... koobarra

- Forewing fork 1 longer than its footstalk; forewing posterior anastomosis not marked by zig-zag pattern .16

16. Male genitalia, in ventral view, with inferior appendages stout throughout length, about 1.5 times width, rounded mesially, apically a small curved lateral process (Fig. 57); tergite X broad, apically truncate (Figs 58, 59) .

$\ldots \ldots \ldots \ldots \ldots \ldots \ldots \ldots \ldots \ldots \ldots \ldots$ dilata

- Male genitalia, in ventral view, with inferior appendages stout basally, gradually constricted to about half basal width; tergite $\mathrm{X}$ excavated mesially to form a pair of apically acute lateral processes (Figs 47,48$) \ldots \ldots \ldots \ldots$ $\ldots \ldots \ldots \ldots \ldots \ldots$. spicata (N Qld form)

17. Male genitalia, in lateral view, with a small digitate lobe dorsal to base of inferior appendages (Fig. 38) . O. parka

- Male genitalia, in lateral view, without a small lobe as

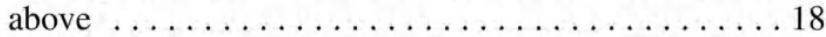

18. Male genitalia, in ventral view, with a lobe on mesial side of inferior appendages (Fig. 69) ......... O. terania

- Male genitalia, in ventral view, without a lobe as above .19

19. Wings uniformly fuscous, vestiture short, dense; in male genitalia, tergite $\mathrm{X}$ comprising a median, tapered lobe between a pair of broadly rounded, membranous lateral lobes (Figs 42, 45) $\ldots \ldots \ldots \ldots \ldots \ldots \ldots \ldots \ldots$

- Wings mottled or with some small markings, or spotted; tergite $\mathrm{X}$ not as above $\ldots \ldots \ldots \ldots \ldots \ldots \ldots \ldots \ldots$

20. Male genitalia, in lateral view, with inferior appendages about same width throughout length, apices not down-

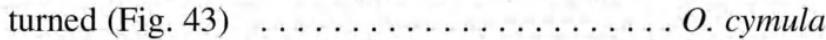

- In genitalia, in lateral view, inferior appendages dilated baso-ventrally, apices down-turned, rounded (Fig. 46) ... O. paracymula

21. In genitalia, in ventral view, inferior appendages broadbased, abruptly narrowed, expanded slightly mesially, distally about width of narrower basal section (Fig. 50); in lateral view, inferior appendages with a broadly rounded basodorsal lobe, distally tapered, slender (Fig. 52) . . . .

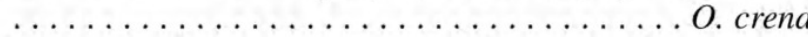

- In genitalia, in ventral view, inferior appendages not as

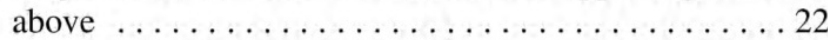

22 In genitalia, in lateral view, inferior appendages truncate apically, in distal half about half width at base (Fig. 40); in ventral view, a distinct notch on mesial margin at about two-thirds length (Fig. 39) ............ O. arcada

- Not as above ................... 23

23. In genitalia, inferior appendages in lateral view expanded dorsally, narrow in distal two-thirds (Fig. 36); in ventral view gently curved inwards and tapered to acuminate apices (Fig. 34) ................. . cracenta

- Not as above .................... 24 
24. In genitalia, in ventral view, inferior appendages stout basally gradually curved and constricted to narrowly rounded apex; preanal appendages rounded (Figs 31-33) .

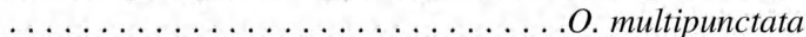

- In genitalia, in ventral view, inferior appendages stout at base, abruptly narrowed to form slender disto-lateral lobes; preanal appendages in dorsal view triangular, in lateral view slender, tapered (Figs 26-28) ..... O. aeoloptera

25 . Forewing distinctly and coarsely patterned, dark brown and fuscous (Fig. 80) $\ldots \ldots \ldots \ldots \ldots$. ornata

- Forewing not as above, but may be spotted, moth-like 26

26. Male genitalia with, tergite $X$ hairy, rounded, cleft

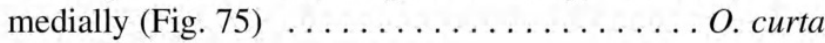

- Tergite $\mathrm{X}$ not as above $\ldots \ldots \ldots \ldots \ldots \ldots \ldots . \ldots 27$

27. In genitalia, tergite $X$ membranous with apicolateral angles acute (Fig. 48) . . . . . . . . O. spicata (NT form)

- In genitalia, tergite $X$ not as above ......... 28

28. Wings not spotted; in genitalia, in lateral view, preanal appendages narrow, length $2 \mathrm{x}$ width (Figs 78, 79) .....

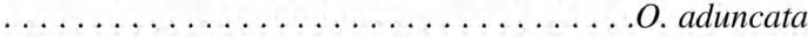

- Wings spotted (Figs 87, 88); in genitalia, in lateral view, preanal appendages broadly rounded or subtriangular (Figs

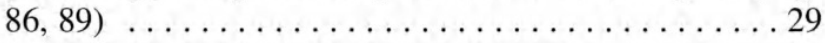

29. In genitalia, tergite $X$ in dorsal view minaret-shaped (Fig. $85)$; inferior appendages in ventral view with tiny hook at mesial angle ............... cepaforma

- Male genitalia with, tergite $\mathrm{X}$ in dorsal view broad, apically truncate (Fig. 90); inferior appendages in ventral view without tiny hook at mesial angle $\ldots \ldots \ldots$. $\ldots \ldots \ldots \ldots \ldots \ldots \ldots \ldots \ldots \ldots$. dostinei

\section{Key to males of Oecetis longiterga-group in Australia}

1. Forewing Cu1a straight (Fig. 94); in genitalia a single paramere with apex spiked and toothed (Figs 98, 100) .. $\ldots \ldots \ldots \ldots \ldots \ldots \ldots \ldots$. crosslandi

- Forewing Cula with distinct curve (Fig. 91); male genitalia not as above $\ldots \ldots \ldots \ldots \ldots \ldots \ldots$

2. Male genitalia with, in lateral view, a sclerotised process dorsal to inferior appendages (Fig. 97); in ventral view, forming a stout structure, angled mesially at midlength

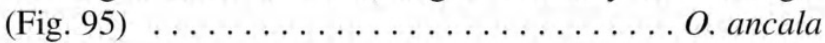

- Male genitalia without any sclerotised processes (Figs 92, 93) $\ldots \ldots \ldots \ldots \ldots \ldots \ldots \ldots \ldots$ digitata

\section{Species of the laustra-group}

\section{Oecetis laustra Mosely}

Figures 1-3, 101

Oecetis laustra Mosely in Mosely and Kimmins, 1953: 295, fig. 209. -Neboiss, 1977: 146, figs 788-791. - Neboiss, 1982: 321, figs 129-131.

Material examined. Holotype. Male, Yanchep, WA, 31 $32.9^{\prime} \mathrm{S}$ $115^{\circ} 41.2^{\prime} \mathrm{E}(\mathrm{BMNH})$ WARI
Diagnosis. Wings slightly mottled, fuscous-brown/grey, with short hair on veins; forewing (Fig. 1) length 4 times maximum width, footstalk of fork 1 slightly shorter than fork, posterior anastomosis almost linear, to linear, very slightly oblique; hindwing (Fig. 1) with $M$ branched; in male genitalia, inferior appendages (Figs 2-3) broad and stout, in ventral view, a small mesial tooth at about two-thirds length, in lateral view broadly rounded above and below in basal half, distally about one-third maximum basal width; preanal lobes short, rounded.

Distribution. Widespread in Australia, in lentic and slower lotic waters, but not collected from arid central Australia (Fig. 101).

Remarks. The stouter inferior appendages distinguish $O$. laustra from $O$. atarpa and $O$. aeoloptera, the absence of a sharp, anteriorly directed mesial hook on the inferior appendages distinguishes it from $O$. pseudolaustra sp. nov. Oecetis laustra is one of the most widespread and abundant of Australian Oecetis species, although unlike $O$. pechana it has not been collected from the natural and artificial waterbodies of arid inland Australia. In its present concept, the species is quite variable across its range, and may eventually be demonstrated to be several species. The posterior anastomosis of the forewing is usually more or less linear, but may be slightly stepped; and in the male genitalia, the form of the mesial margin of the inferior appendages may be more or less dentate (Mosely and Kimmins, 1953: fig. 209c, d; Neboiss, 1986: 269).

\section{Oecetis pseudolaustra sp. nov.}

Figures 4-6, 102

Material examined. Holotype, male, Qld, Lakefield NP, Sweetwater Lagoon, 11 Oct 2002, G. Theischinger (ANIC).

Paratypes. 21 males, 1 female, data as for holotype (ANIC); 18 males, 3 females, Cape York Peninsula, Wenlock River crossing (to Iron Range), 5 Oct 2002, G. Theischinger (ANIC, NMV, QM).

Diagnosis. As $O$. laustra except inferior appendages with a sharp anteriorly directed mesial hook.

Description. Tibial spurs 1, 2, 2. Male forewing length 3.4-5.0 $\mathrm{mm}$. Wings as for $O$. laustra, mottled fuscous/brown, densely covered with short hair. Male genitalia as in Figs 4-6. Preanal appendages in dorsal view rounded apically and about as long as wide. Tergite $\mathrm{X}$ a single membranous plate, narrowly truncate apically. Inferior appendages stout, in lateral view broadly rounded above and below in basal half, distally about one-third maximum basal width, in ventral view with a sharp mesial hook on inner margin. Phallus length in lateral view equal to width.

Distribution. Far north of Cape York Peninsula, northern Qld (Fig. 102).

Remarks. At the Lakefield National Park site, this species was collected together with several specimens of Oecetis laustra, which could be distinguished by their slightly darker colour as well as the distinctive difference in male genitalia. The stouter inferior appendages distinguish $O$. pseudolaustra and $O$. laustra from $O$. atarpa and $O$. aeoloptera. 


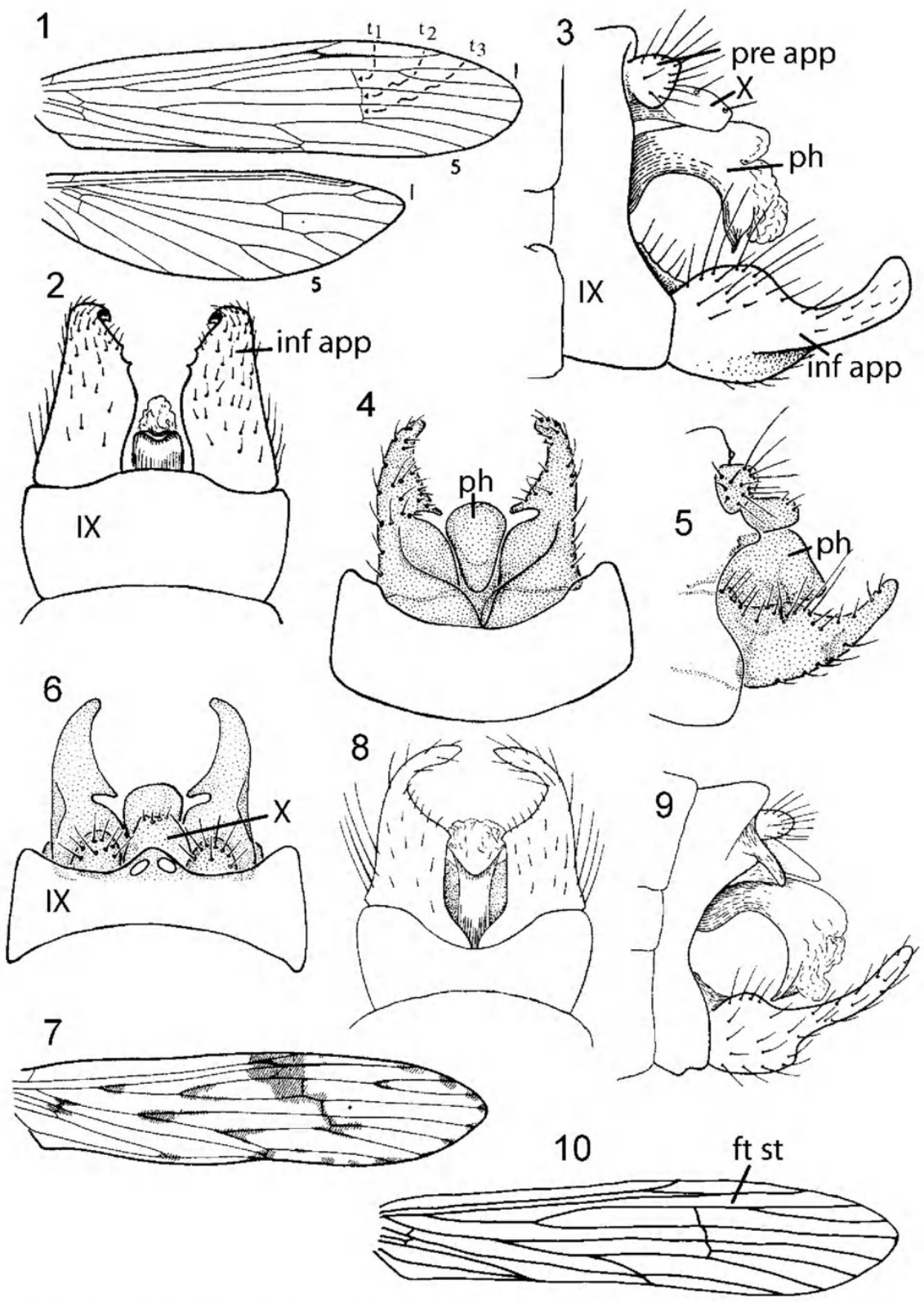

Figures 1-3, Oecetis laustra Mosely, 1953: 1, wings, labelled to indicate forks present and terminology applied to crossveins of posterior anastomosis; 2-3, male genitalia, ventral and lateral views [after Mosely and Kimmins, 1953]. inf app, inferior appendages; ph, phallus; pre app, preanal appendage; IX, X, abdominal segments IX and X; 1, 5, forks in wing venation.

Figures 4-6, O. pseudolaustra sp. nov., male genitalia, ventral, dorsal and lateral views. X, abdominal segment X.

Figures 7-9, O. atarpa Mosely: 7, forewing; 8, 9, male genitalia, ventral and lateral views [from Mosely and Kimmins, 1953].

Figure 10, O. scirpicula Neboiss, forewing [after Neboiss, 1977]. ft st, foot stalk of fork 1.

\section{Oecetis atarpa Mosely}

Figures 7-9, 103

Oecetis atarpa Mosely and Kimmins, 1953: 287, fig. 202.

Material examined. Paratype. Male, National Park [Royal National Park], NSW, $34^{\circ} 3.9^{\prime} \mathrm{S} 151^{\circ} 3.1^{\prime} \mathrm{E}$ (BMNH).

Other material. 27 samples in ANIC and NMV.

Diagnosis. Forewing (Fig. 7) length 3-4 times maximum width, fork 1 with footstalk, posterior anastomosis with $\mathrm{t} 2$ and $\mathrm{t} 3$ contiguous, $\mathrm{t} 1$ more proximal than both $\mathrm{t} 2$ and $\mathrm{t} 3$; in the male genitalia (Figs 8, 9) abdominal segment IX in lateral view produced distally in a down-turned peg ventral to preanal lobe; and inferior appendages in lateral view long and slender distally, rounded and swollen basally with basal third about 4 times broader than distal two-thirds which is less than twice length of basal section.

Distribution. Throughout Australia but only small scattered collections taken in NT (Fig. 103).

Remarks. Closely resembling Oecetis scirpicula and O. aeoloptera in form of male genitalia but distinguished by the 
stepped arrangement of crossveins in the posterior anastomosis in forewing, and the dorsolateral 'peg' on abdominal segment IX. The very slight difference between $O$. atarpa and O. scirpicula Neboiss-mainly the more strictly linear posterior anastomosis in the forewing of the latter and in the male genitalia a small difference in proportions in inferior appendages - is well within the range of variation exhibited by other Australian Oecetis, particularly those with temperate to tropical distributions. For the present, however, the two names are retained.

\section{Oecetis scirpicula Neboiss}

Figures 10, 11, 104

Oecetis scirpicula Neboiss, 1977: 149, figs 804-807.

Material examined. Tas.: 2 males, Canal at Interlaken, $42^{\circ} 8.8^{\prime} \mathrm{S}$ $147^{\circ} 10.5^{\prime} \mathrm{E}, 2$ Feb 1966, G.E. Edmunds (ANIC); males, females, Navarre River, $42^{\circ} 9.5^{\prime} \mathrm{S} 146^{\circ} 8.6^{\prime} \mathrm{E}, 12$ Feb 1967, E.F. Riek (ANIC); 1 male, Olga-Hardwood River, Saddle buttongrass plain, $42^{\circ} 57.8^{\prime} \mathrm{S}$ 145 55.3'E, 4 Apr 1977, Allbrook, Richardson, Swain (NMV); 2 males, 12 km NNE Bronte Park, 42 ${ }^{\circ} 02^{\prime} \mathrm{S} 146^{\circ} 33^{\prime} \mathrm{E}, 2$ Feb 1983, J.C. Cardale (ANIC); male, 2 females, Pelion Hut, $3 \mathrm{~km} \mathrm{~S} \mathrm{Mt} \mathrm{Oakleigh,}$ $41^{\circ} 50^{\prime} \mathrm{S} 146^{\circ} 03^{\prime} \mathrm{E}$, Feb.1990, E.S. Nielsen, it trap (ANIC).

Diagnosis. Forewing (Fig. 10) length about 4 times maximum width, veins of the posterior anastomosis contiguous; in male genitalia (Fig. 11), abdominal segment IX produced posteriorly to form a triangular process ventral to preanal appendages and inferior appendages with distal slender distal portion twice length of basal portion.

Distribution. Tas. (Fig. 104).

Remarks. Although males of this species closely resemble those of $O$. atarpa, as noted above, the name scirpicula is retained here for these Tasmanian specimens. The two species have only slight difference in forewing venation and in the genitaliaproportions of the inferior appendages, differences that are well within the range of variability accepted for other species. Size differences, however, are considerable, the anterior wing length of around $9 \mathrm{~mm}$ for $O$. scirpicula being several millimetres longer than in $O$. atarpa. In addition, females of $O$. scirpicula lack the broadly rounded dorsal lobes seen in $O$. atarpa (Mosely and Kimmins, 1953: fig. 203c), having in their place a pair of almond-shaped lobes.

\section{Oecetis inscripta Kimmins}

Figures 12-14, 105.

Oecetis inscripta Kimmins in Mosely and Kimmins, 1953: 294, fig. 208. -Neboiss, 1977: 148, figs 801-803. - Neboiss, 1982: 323, figs 127, 128.

Material examined. Holotype. Male, Bathurst, NSW (BMNH). 52 samples in ANIC, NMV and WARI.

Diagnosis. Forewing (Fig. 12) length almost 5 times maximum width, lamina marked with bold dark streaks, not the more usual dark spots or patches; footstalk on fork 1 , and $\mathrm{t} 1$ and $\mathrm{t} 2$ contiguous, $\mathrm{t} 3$ more proximal than the 2 other crossveins of the posterior anastomosis. In the male genitalia (Figs 13, 14), a rounded basodorsal lobe on the inferior appendages and infer-ior appendages in ventral view slender with length 3 times maximum width, irregularly tapered towards apex.

Distribution. Eastern Australia from Tas. northwards almost to Cairns, north-eastern Qld, probably widespread in Murray-Darling basin (Fig. 105).

\section{Oecetis brevidentata sp. nov.}

Figures 15-18, 106

Oecetis sp. E. - Wells, 1991: figs 138, 172-176.

Material examined. Holotype, male, NT, Katherine River Gorge National Park, $13^{\circ} 23.9^{\prime} \mathrm{S} 133^{\circ} 10.0^{\prime} \mathrm{E}, 13$ Aug 1979, J. Blyth (NMV T18524).

Paratypes. NT: 4 males, 3 females, same data as for holotype (NMV); 1 male, Kakadu National Park, Jim Jim Creek, 3 km below falls, $13^{\circ} 15.9^{\prime} \mathrm{S} 132^{\circ} 51.1^{\prime} \mathrm{E}, 1 \mathrm{Sep} 1979$, J. Blyth (NMV); 1 male, ARRS, South Alligator River, at Gimbat OSS Station, $13^{\circ} 34.3^{\prime} \mathrm{S}$ $132^{\circ} 36.7^{\prime} \mathrm{E}, 24$ May 1988, A. Wells and P. Suter (NMV); 9 males, 1 female, South Alligator River below BHP camp, 25 May 1988, P. Suter and A. Wells (NMV); 2 males, ARRS, SAR site 1, 14 Jun 1988, P. Dostine (NTM); 1 male, 1 female, ARRS, South Alligator River, at Gimbat OSS Station, $13^{\circ} 34.3^{\prime} \mathrm{S} 132^{\circ} 36.7^{\prime} \mathrm{E}, 28$ Apr 1989, P. Dostine (NTM); 2 males, 1 female, $12^{\circ} 48^{\prime} \mathrm{S} 132^{\circ} 49^{\prime} \mathrm{E}$, Kakadu National Park, Baroalba Springs, 4 Oct 1991, A. Wells (NTM).

Other material. NT: male, 3 females, ARRS South Alligator River above Fisher Creek jen, $13^{\circ} 34^{\prime} \mathrm{S} 132^{\circ} 34^{\prime} \mathrm{E}, 18-20$ Apr 1989, Suter and Wells (NTM); 2 males, female, Gunlom (as UDP Falls), $13^{\circ} 24.9^{\prime} \mathrm{S}$ $132^{\circ} 26.0^{\prime} \mathrm{E}, 18-19 \mathrm{Jul} 1980$, M.B. Malipatil (NTM).

Diagnosis. Forewing with length about 5 times maximum width, lamina marked by a distinctive cross formed by dark membrane and setae on $\mathrm{t} 1$ and $\mathrm{t} 2$ and their junction with R3-4; $\mathrm{t} 1$ and $\mathrm{t} 2$ contiguous, $\mathrm{t} 3$ well proximal of both. In male $\mathrm{g}$ enitalia, inferior appendages in ventral view slender and curving, and in lateral view with apices acute and directed ventrally, rather than straight as in $O$. multipunctata.

Description. Tibial spurs 1, 2, 2. Male forewing length 6.1-7.8 $\mathrm{mm}$. Wings with vestiture of even length, without spots, but forewing (Fig. 15) with distinctive dark cross marking the junctions of $\mathrm{t} 1$ and $\mathrm{t} 2$ with $\mathrm{R}$, footstalk on fork 1 longer than fork. Male genitalia as in Figs 16-18. Segment IX widest midlaterally; preanal appendages separate, ovoid. Segment X elongate, membranous, dorsal process short, slender. Inferior appendages narrow, tapered, slightly bowed, apices downturned in lateral view. Phallus with length about twice width, beak-like apically.

Distribution. Alligator Rivers region of northern NT (Fig. 106).

Remarks. The larva of this species is unique among Australian Oecetis species. Associated as 'sp. E' by Wells (1991), it is the only Oecetis species of which I am aware that has short, blunt mandibles. This feature suggests that $O$. brevidentata has dietary habits quite different from other congeners. It may well be a detritivore.

Etymology. Latin, descriptive of the larval mandibles. 

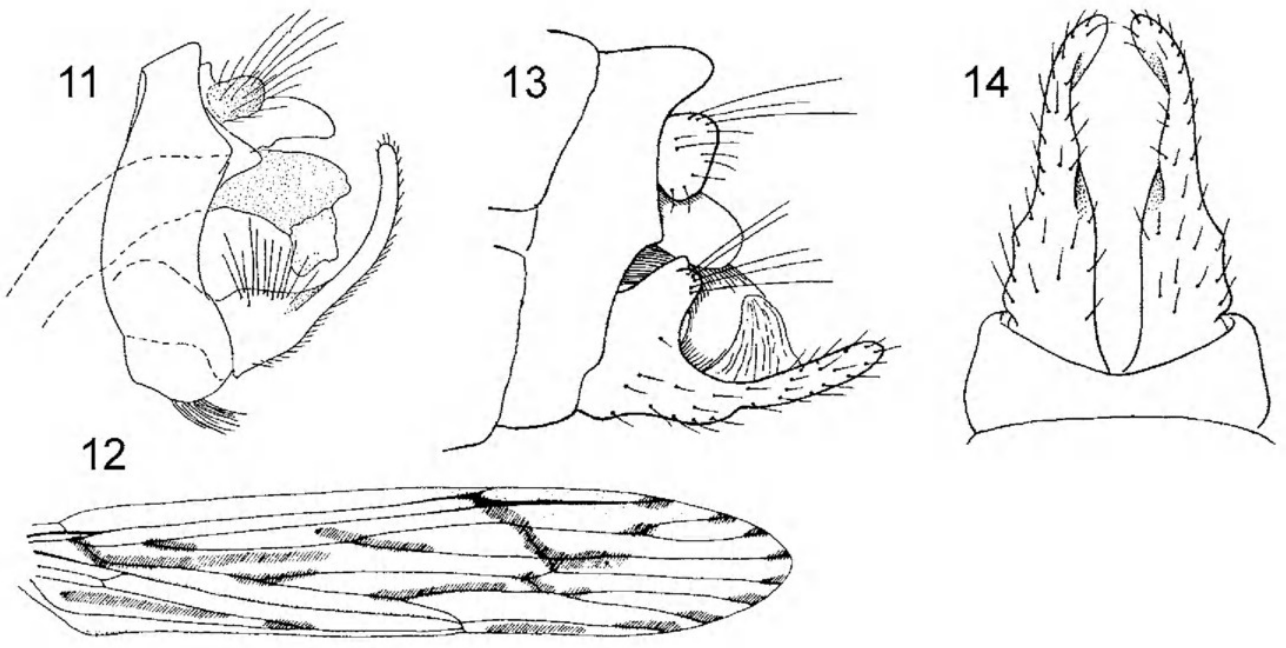

15
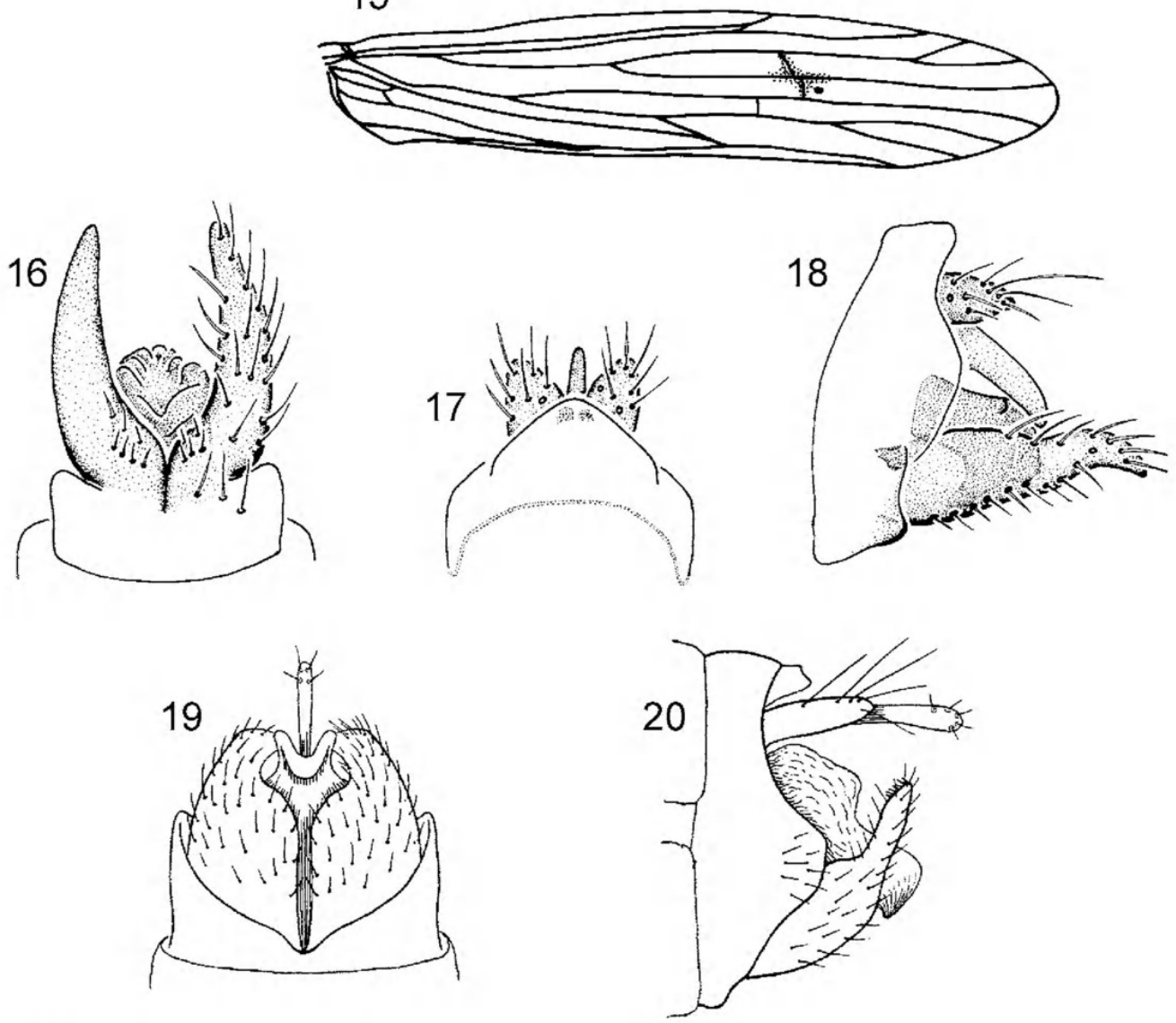

Figure 11, Oecetis scirpicula Neboiss, male genitalia, lateral view [from Neboiss, 1977].

Figures $12-14, O$. inscripta Kimmins: 12 , forewing; 13, 14, male inferior appendages in ventral view, genitalia in lateral view [from Mosely and Kimmins, 1953].

Figures $15-18, O$. brevidentata sp. nov.: 15, forewing; 16-18, male genitalia, ventral, dorsal and lateral views.

Figure 19, 20, O. asmanista Mosely, male genitalia, ventral and lateral views [from Mosely and Kimmins, 1953].

\section{Oecetis asmanista Mosely}

Figures 19, 20, 107

Oecetis asmanista Mosely and Kimmins, 1953: 282, fig. 199. Neboiss, 1977: 147, figs 792-795.

Oecetis ochracea Jaquemart, 1965: 23. [Junior homonym of Oecetis ochracea (Curtis, 1825)], (synonymy by Neboiss, 1977: 147).
Oecetis geevestonia Neboiss, 1974: 15. [Unnecessary replacement name for $O$. ochracea Jaquemart.]

Material examined. Holotype. male, Tas. (BMNH).

Tas.: Male, female, Derwent Bridge, 12 Feb 1967, E.F. Riek (ANIC); male holotype (BMNH); 1 male, Olga Camp, Gordon-Smith River junction, $42^{\circ} 39.1^{\prime} \mathrm{S} 145^{\circ} 48.0^{\prime} \mathrm{E}, 2$ Feb 1976, Howard, Suter (NMV); males, females, West Bay River, Margate, $43^{\circ} 1.7^{\prime} \mathrm{S}$ 

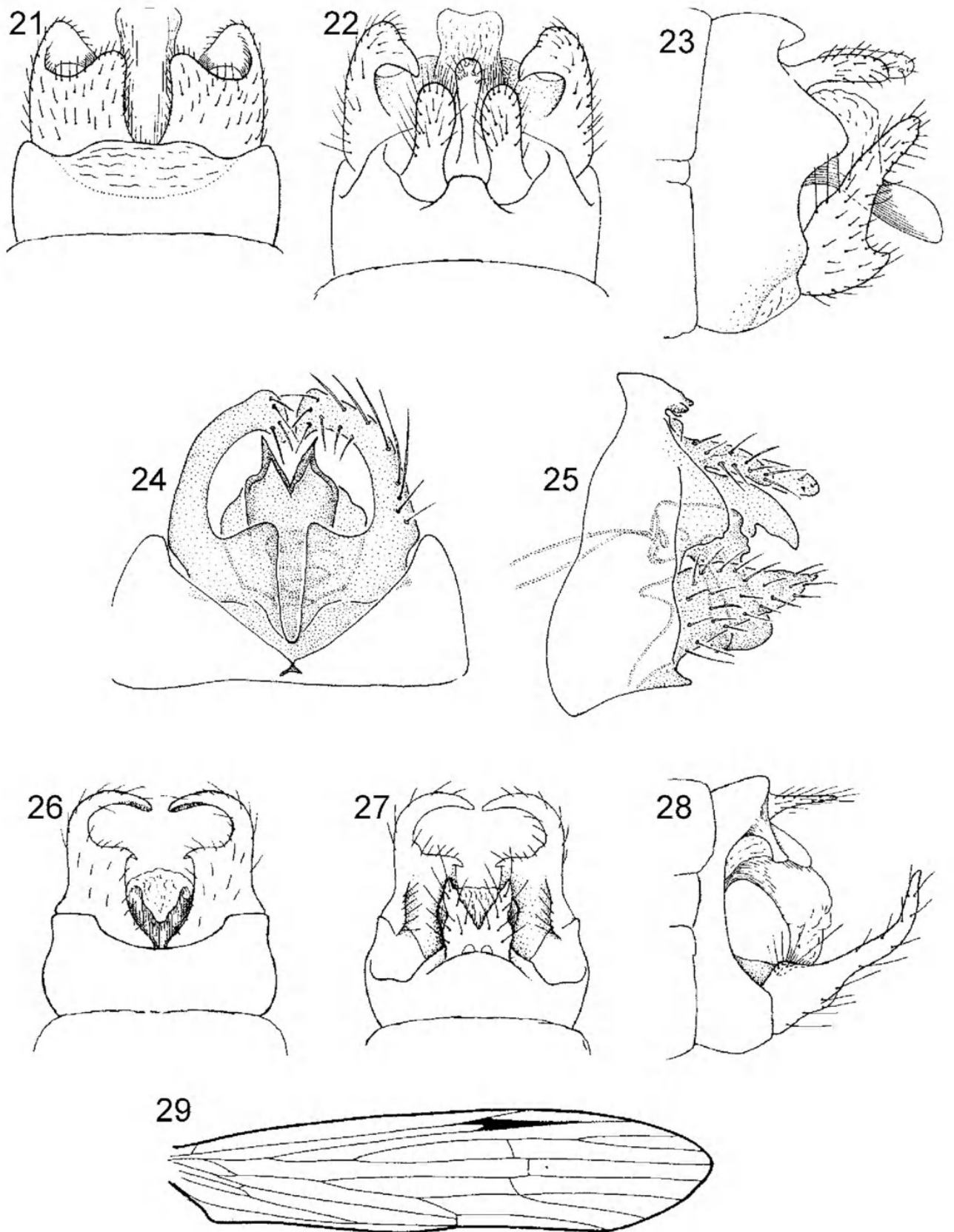

Figures 21-23, Oecetis minasata Mosely, male genitalia, ventral, dorsal and lateral views [from Mosely and Kimmins, 1953]. Figures 24-25, O. erskinensis sp. nov., male genitalia, ventral, dorsal and lateral views.

Figures 26-29, O. aeoloptera Kimmins: 26-28, male genitalia, ventral, dorsal and lateral views; 29, forewing [from Mosely and Kimmins, 1953].

147¹5.7'E, 6 Jan 1977, Coleman, Neboiss, Allbrook (NMV); males, females, Franklin River-Roaring Creek junction, 4 km above Gordon River junction, 8 Jan 1977, Coleman, Neboiss, Allbrook (NMV); 1 female, Swamp nr Olga River, $19 \mathrm{~km}$ above Gordon River Junction, $42^{\circ} 42.8^{\prime} \mathrm{S} 145^{\circ} 46.8^{\prime} \mathrm{E}, 13$ Jan 1977 , Neboiss and Swain (NMV); 3 males, Pelion Hut, $3 \mathrm{~km} \mathrm{~S}$ Mt Oakleigh, $41^{\circ} 50^{\prime} \mathrm{S} 146^{\circ} 03^{\prime} \mathrm{E}$, 6-11 Mar 1991 at light, M. Horak, P. McQuillan (ANIC). Vic: male, Tanjil River Jcn, $10 \mathrm{~km} \mathrm{~N}$ of Willow Grove, 38 4.2'S 146 ${ }^{\circ} 10.6^{\prime} \mathrm{E}, 18$ Dec 1973, A. Neboiss (NMV).

Diagnosis. Forewing length over 4 times maximum width, fork 1 with footstalk and $\mathrm{t} 1$ and $\mathrm{t} 2$ contiguous, $\mathrm{t} 3$ only slightly more proximal than $\mathrm{t} 1$ or $\mathrm{t} 2$. In male genitalia (Figs 19, 20), inferior appendages skittle-shaped in lateral view being roundly constricted at two-thirds length, narrow distally; tergum $\mathrm{X}$ a narrow process, almost twice as long as preanal appendages.

Distribution. Tas. and south-central Vic. (one specimen only) (Fig. 107).

\section{Oecetis minasata Mosely}

Figures 21-23, 108

Oecetis minasata Mosely in Mosely and Kimmins, 1953: 282, fig. 198. - Neboiss, 1977: 146, figs 784-787.

Material examined. Holotype. Male, Tas. (BMNH). 21 samples in ANIC and NMV. 
Diagnosis. Wings dark brownish, unicolorous, with long downy hair on the veins; forewing length 4 times maximum width, posterior anastomosis contiguous. In male genitalia (Figs 21-23) in ventral view, inferior appendages with basal portion as long as wide, roundly produced ventromesially, and constricted and sharply returned forming dorsolateral lobes; preanal appendages about 3 times as long as wide.

Distribution. South-eastern Australia: from south-eastern NSW, ACT, Vic. and Tas. (Fig. 108).

Remarks. Males of $O$. minasata are distinguished from those of $O$. erskinensis by the rounded apex of the phallus, and from $O$. asmanista by the angular ventral expansion of the inferior appendages and the shorter median process of tergum X. The female lacks the patches of bristles characteristic of $O$. asmanista. In form of male genitalia, O. cymula and $O$. paracymula also show resemblance, but $O$. minasata can be distinguished from the two species by the crossveins of the posterior anastomosis contiguous, not stepped.

\section{Oecetis erskinensis sp. nov.}

Figures 24, 25

Material examined. Holotype, male, Lord Howe Island, Erskine Valley, Erskine Creek, 21-22 Nov 1996, Wells and Mound (ANIC). Paratype. Male, data as for holotype (ANIC).

Other material. Larvae, pupa, locality as for holotype, 24 Dec 2001, Wells and Mound (ANIC).

Diagnosis. As for O. minasata, but in male genitalia (Figs 24, 25) setae on inturned apices of inferior appendages are all about equal in size and length, and in ventral view the apex of phallus is divided to form 2 apically acute, sclerotised lobes.

Description. Spurs 1, 2, 2. Male forewing length, $7.9 \mathrm{~mm}$. Wings of typical shape, forewing fork 1 with footstalk less than half length of fork, posterior anastomosis with $\mathrm{t} 1$ and $\mathrm{t} 2$ linear, oblique, $\mathrm{t} 3$ slightly more proximal, angled. Male genitalia, Figs 22 , 25. Segment IX narrow, preanal appendages more than twice as long as wide, rounded apically. Segment X slender, almost same width throughout length. Inferior appendages in ventral view clasper-shaped, inturned subapically, apices obliquely truncate. Phallus very short, with distal sharply downturned section almost twice length of basal portion, rounded basally, bifurcate, lobes sclerotised, acute apically.

Remarks. Oecetis minasata and $O$. erskinensis are closely similar, possibly sister species, distinguished by genitalic character states as noted under $O$. minasata.

Etymology. Named for the collecting site.

\section{Oecetis aeoloptera Kimmins}

Figures 26-29, 109

Oecetis aeoloptera Kimmins in Mosely and Kimmins, 1953: 287, fig. 201.

Material examined. Holotype. Male, Murwillumbah, NSW (BMNH), 21 samples in ANIC and NMV.
Diagnosis. Forewing (Fig. 29) length 4 times maximum width, posterior anastomosis clearly non-linear, with $\mathrm{t} 2$ more distal than $\mathrm{t} 1$ and $\mathrm{t} 3$ which are both approximately equal; in male genitalia (Figs 26-28) inferior appendages pincer-shaped in ventral view, in lateral view long and slender distally; preanal lobes discrete, triangular.

Distribution. Eastern Vic., more north-eastern NSW, southeastern and northern Qld, northern NT to northern WA (Fig. 109).

Remarks. In male genitalic features $O$. aoeloptera closely resembles $O$. atarpa and $O$. scirpicula but is distinguished by the more attenuate inferior appendages, and preanal lobes elongate triangular in ventral view, in lateral view, slender, tapered, rather than rounded.

\section{Oecetis multipunctata Ulmer}

Figures 30-33, 110

Oecetis multipunctata Ulmer, 1916: 19. —Mosely and Kimmins, 1953: 293, fig. 206.

Material examined. 48 samples in ANIC and NMV.

Diagnosis. Wings with pattern of dark spots (Fig. 30); forewing length about 4.5 times maximum width, fork 1 with footstalk and veins of the posterior anastomosis clearly stepped. In male genitalia (Figs 31-33) segment X simple, short and slender; inferior appendages without any lobes or processes, length about 3 times width, tapered distally; and phallus curved downwards.

Distribution. Widespread in northern and eastern Qld, and also collected from north-eastern NSW (Fig. 110).

Remarks. Oecetis cepaforma, O. dostinei and O. parka also have spotted wings, but $O$. cepaforma and $O$. dostinei have the forewings broad and 'floppy' compared to those of $O$. multipunctata and $O$. parka. These last two species are distinguished by male genitalic features, particularly the presence of the digitate laterobasal lobe on the inferior appendages of $O$. parka, and the more rounded, rather than angular shape of the inferior appendages of $O$. multipunctata. The male genitalia of Oecetis multipunctata closely resemble those of the NT $O$. brevidentata from which $O$. multipunctata is distinguished by its spotted wings and shape of the phallus. Also in $O$. multipunctata, in lateral view, the inferior appendages are almost straight, whereas in $O$. brevidentata sp. nov. the apices are down-turned.

\section{Oecetis cracenta sp. nov.}

Figures 34-36, 111

Material examined. Holotype, male, WA, King Edward River, 4-5 May $1992,1^{\circ} 52.57^{\prime} \mathrm{S} 126^{\circ} 12.08^{\prime} \mathrm{E}$, P.S. Cranston (ANIC).

Paratypes. NT: 2 males, 3 females, Litchfield National Park, Florence Falls, $13^{\circ} 03^{\prime} \mathrm{S} 130^{\circ} 47^{\prime} \mathrm{E}, 9$ Apr 1991, Wells and Horak (NMV).

Diagnosis. Wings mottled, not noticeably spotty; forewing length about 4 times maximum width, fork 1 with footstalk, and 

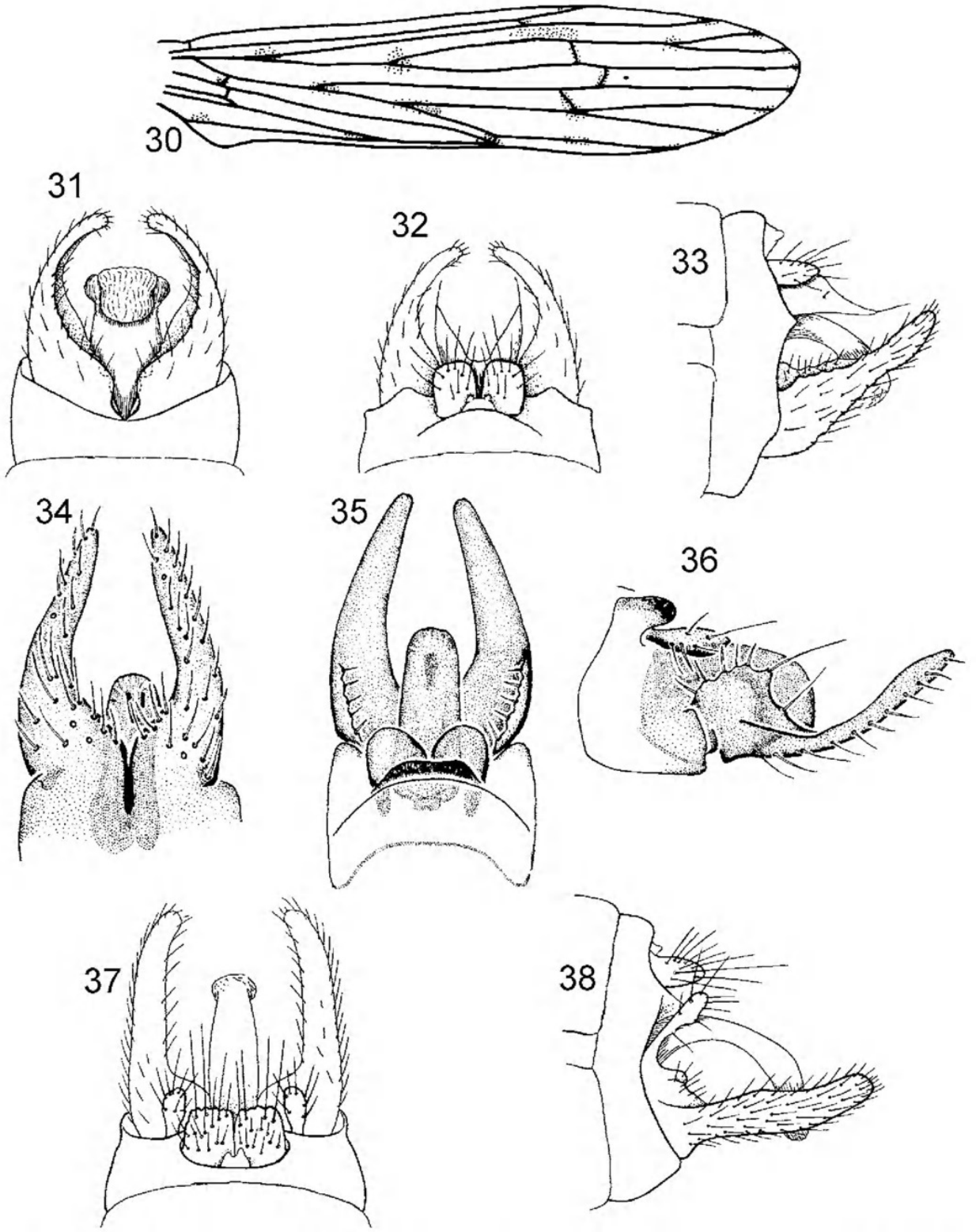

Figures 30-33, Oecetis multipunctata Ulmer: 30, forewing; 31-33, male genitalia, ventral, dorsal and lateral views [from Mosely and Kimmins, 1953].

Figures 34-36, O. cracenta sp. nov., male genitalia, ventral, dorsal and lateral views.

Figures 37, 38, O. parka Mosely, male genitalia, dorsal and lateral views [from Mosely and Kimmins, 1953].

crossveins of posterior anastomosis clearly stepped. In male genitalia, in ventral view, the inferior appendages taper smoothly from base to apex and lack a mesial process, and the preanal appendages are rounded.

Description. Tibial spurs 0, 2, 2. Male forewing length 4.9-5.4 $\mathrm{mm}$. Wings with vestiture of even length, without scales or spots, but forewing with a distinctive dark line marking the distal crossveins; forewing with footstalk on fork 1 and $\mathrm{t} 2$ more distal than $\mathrm{t} 1$ and $\mathrm{t} 3$. Male genitalia as in Figs 34-36. Segment IX short; preanal appendages in lateral view narrow at base and apically rounded, in ventral view stout, rounded. Inferior appendages in lateral view slightly expanded basodorsally, slender in distal two-thirds, in ventral view closely appressed basomesially, tapered to narrow apices, curved mesially, straighter distally. Phallus strongly downturned, sharply 'beaked' apically.

Distribution. Kimberley region of northern WA, and northern NT (Fig. 111).

Remarks. Seen in lateral view, the male genitalia of this species resemble closely those of $O$. crena from which it is distinguished by the smoothly rounded inner margin of the inferior appendages.

Etymology. Latin, descriptive of the male inferior appendages. 

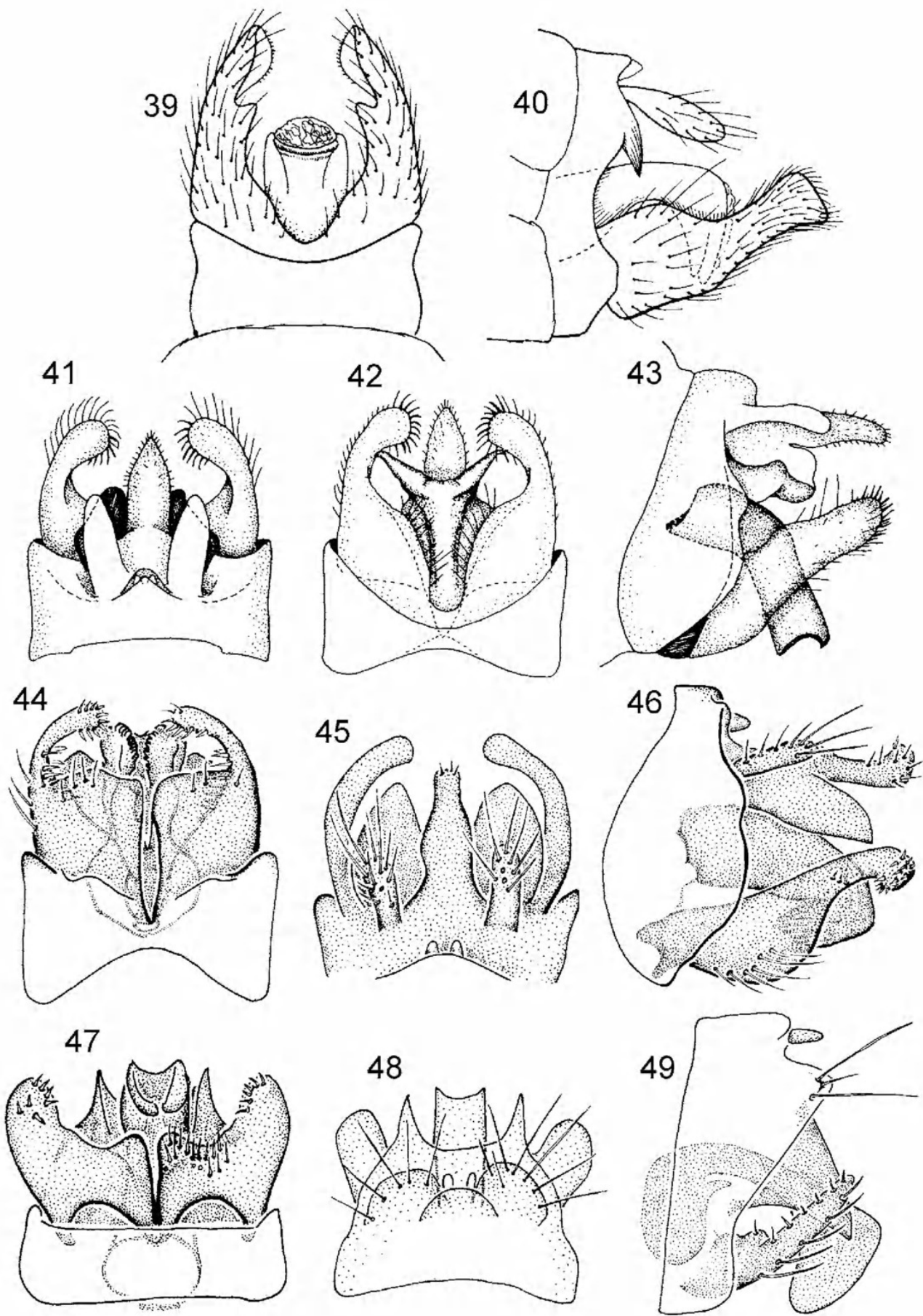

Figures 39, 40, Oecetis arcada Mosely, male genitalia, ventral and lateral views [from Mosely and Kimmins, 1953].

Figures 41-42, O. cymula Neboiss, male genitalia, ventral, dorsal and lateral views [from Neboiss, 1982].

Figures 43-46, O. paracymula, sp. nov., male genitalia, ventral, dorsal and lateral views.

Figures 47-49, O. spicata sp. nov., male genitalia, ventral, dorsal and lateral views.

\section{Oecetis parka Mosely}

Figures 37, 38, 112

Oecetis parka Mosely in Mosely and Kimmins, 1953: 290, fig. 205.

Material examined. Holotype. Male, NSW, National Park [?the Royal National Park] (BMNH).

15 samples in ANIC and NMV.
Diagnosis. Wings spotted; forewing length about 4 times maximum width, footstalk present, veins of posterior anastomosis clearly stepped with $\mathrm{t} 2$ more distal than $\mathrm{t} 1$ and $\mathrm{t} 3$. In male genitalia (Figs 37, 38) an unusual dorsal digitiform process arises at the base of the inferior appendages, which are about 4 times as long as wide, and almost rod-shaped and straight in distal three-quarters of length. 
Distribution. Eastern Vic., east-central NSW and north-eastern Qld (Fig. 112).

Remarks. The dorsal process at the base of the inferior appendages is unique among Australian Oecetis, but closely resembles similar structures seen in some Setodes species described by Schmid (1987), for example S. apitayati and S. uttamavarna. This species is never common in collections.

\section{Oecetis arcada Mosely}

Figures 39, 40, 113

Oecetis arcada Mosely, in Mosely and Kimmins, 1953: 290, fig. 204. - Neboiss, 1977: 148, figs 796-800.

Oecetis albodecorata Jaquemart, 1965 (Synonymy by Neboiss, 1977: 148)

Material examined. Holotype of $O$. arcada. Male, Cradle Mountains, Tas. (BMNH).

18 samples in NMV and ANIC.

Diagnosis. Male genitalia (Figs 39, 40), with the inferior appendages curving upwards and apically truncate; preanal appendages almost 3 times longer than wide. Forewing length less than 4 times maximum width; footstalk on fork 1 and $t 2$ more distal than $\mathrm{t} 1$ and $\mathrm{t} 3$.

Distribution. Widespread in Tas. (Fig. 113).

\section{Oecetis cymula Neboiss}

Figures 41-43, 114

Oecetis cymula Neboiss, 1982: 323, figs 132-136.

Material examined. WA: 3 paratype males, same data as for holotype (ANIC); paratypes, females, same locality as holotype, 22 Nov 1978, A. Neboiss (ANIC); males, females, 15 miles NW of Walpole, 15 Nov 1958, E.F. Riek (ANIC); males, females, Harvey River nr Harvey Falls, $15 \mathrm{~km} \mathrm{E}$ of Harvey, 33⒌5'S 116 $2.0^{\circ} \mathrm{E}, 21$ Nov 1978, A. Neboiss (ANIC).

Diagnosis. Forewing length almost 5 times maximum width, footstalk on fork 1 about half as long as the fork, long downy hairs along wing veins, and $\mathrm{t} 2$ more distal than $\mathrm{t} 1$ and $\mathrm{t} 3$. In male genitalia (Figs 41-43), ventral view, tergum $X$ tapers to an attenuate apex; length of median process of tergum $\mathrm{X}$ exceeds length of preanal appendages and inferior appendages are well separated mesially, thus lacking (when viewed laterally) an expanded ventral projection near the base. Females have on each side on segment VIII an area of bristle-like setae.

Distribution. South-western WA (Fig. 114)

Remarks. Oecetis cymula closely resembles $O$. paracymula but has a tibial spur count of $1,2,2$, whereas the latter has $0,2,2$, and $O$. cymula has fine setae apically and on the mesial margin on the inferior appendages whereas $O$. paracymula has shorter, stout almost peg-like setae.

Oecetis paracymula sp. nov.

Figures 44-46, 115.

Material examined. Holotype, male, NSW, Upper Manning River, 20 km NNW Rawdon Vale, $31^{\circ} 34$ 'S $151^{\circ} 34^{\prime} \mathrm{E}, 19$ Feb 1980, A.A. Calder (NMV T-18511).
Paratypes. NSW, 2 males, data as for holotype (NMV); male, Barrington Tops, 16 Nov 1953, A. Neboiss (NMV).

Other material. 4 females, data as for holotype (NMV).

Diagnosis. Adults densely hairy; forewing shape as for O. cymula, footstalk on fork 1 , and $\mathrm{t} 2$ more distal than $\mathrm{t} 1$ or $\mathrm{t} 3$. In male genitalia, in ventral view, median process of tergum $\mathrm{X}$ constricted close do its base, then swollen, narrowest distally; inferior appendages in ventral view loosely turned inwards in distal third and in lateral view down-turned apically.

Description. Spurs 0, 2, 2. Male forewing length $8.7 \mathrm{~mm}$. Wings with long downy hair along veins; forewing narrow proximally expanded more distally, rounded apically, footstalk on fork 1 about one-fifth length of fork, discoidal and thyridial cells about equal length, anterior anastomosis stepped with $\mathrm{t} 1$ and $\mathrm{t} 2$ almost level, $\mathrm{t} 3$ well anterior to other 2 veins; hind wing slender, narrow. Male genitalia (Figs 44-46). Segment IX broadly convex in lateral view, preanal appendages elongate, slender, more robust in dorsal view, about two-thirds length of median process of tergum $X$. Tergum $X$ with the membranous ventral plate forming a pair of widely almond-shaped lobes, median process constricted towards base, slightly swollen medially, narrower distally, in lateral view, about twice length of anal appendages. Inferior appendages slender in posterolateral half, in lateral view form resembling $O$. minasata, down-turned apically and with short stout setae on terminal third. Phallus stout, strongly down-turned distally.

Distribution. North-eastern NSW (Fig. 115).

Etymology. Showing close resemblance to $O$. cymula.

\section{Oecetis spicata sp. nov.}

Figures 47-49, 116.

Material examined. Holotype, male, Gunshot Creek at Telegraph Crossing, $11^{\circ} 42.9^{\prime} \mathrm{S} 142^{\circ} 20.0^{\prime} \mathrm{E}, 14-15 \mathrm{Feb} 1992$, D. Cartwright and A. Wells (ANIC).

Paratypes, Qld: males, 5 females, Palmer River, 20 Jun 1971, E.F. Riek (ANIC: WTH-1390); 21 males, Laura, Cape York Peninsula, $15^{\circ} 33.9^{\prime} \mathrm{S} 144^{\circ} 27.1^{\prime} \mathrm{E}, 7$ Oct 1979 , M.S. and B.J. Moulds (NMV); 1 male, Qld, Seary's Creek, Rainbow Beach, $25^{\circ} 52^{\prime} \mathrm{S} 153^{\circ} 04^{\prime} \mathrm{E}, 6$ Dec 984, G. Theischinger (NMV); 1 male, Bertie Creek, $1 \mathrm{~km}$ SE Heathlands HS, $11^{\circ} 49.9^{\prime} \mathrm{S} 142^{\circ} 29.0^{\prime} \mathrm{E}, 5$ Feb 1992, D. Cartwright and A. Wells (QM); 6 females, Tributary of Bertie Creek, $250 \mathrm{~m} \mathrm{SW}$ Heathlands HS, $11^{\circ} 45^{\prime} \mathrm{S} 142^{\circ} 35^{\prime} \mathrm{E}, 11 \mathrm{Feb} 1992$, D. Cartwright and A. Wells (QM); 1 male, Cape York Peninsula, Heathlands, Bertie Creek, $11^{\circ} 49.9^{\prime} \mathrm{S} 142^{\circ} 29.0^{\prime} \mathrm{E}, 23$ Mar 1993, M. Crossland (ANIC).

Other material. Qld: male, Mossman, 12 Jun 1971, E.F. Riek (ANIC); males, females, Palmer River, 20 Jun 1971, E.F. Riek (ANIC); male, Peach Creek Crossing, 25 km NNE of Coen, 4-5 Jul 1976, G.B. and S.R. Monteith (ANIC); male, Cockatoo Creek Crossing, $17 \mathrm{~km}$ NW Heathlands, $11^{\circ} 39^{\prime} \mathrm{S} 142^{\circ} 27^{\prime} \mathrm{E}, 25 . v i i-19$ Aug 1992, P. Zborowski, J.C. Cardale, open forest, Malaise \#5 (ANIC); male, Cape York Peninsula, Heathlands, Bertie Creek, 23 Mar 1993, M. Crossland (ANIC). NT: 1 male, South Alligator River, UDP Falls [Gunlom], $13^{\circ} 24.9^{\prime}$ S $132^{\circ} 26.0^{\prime}$ E, 7 Sep 1974, J. Blyth (NTM); 3 males, South Alligator River, UDP Falls [Gunlom], 13⒉9.'S 132 26.0'E, 18-19 Jul 1980, M.B. Malipatil (NTM); 2 males, ARRS, South Alligator River, at Gimbat OSS Stn, $13^{\circ} 34.3^{\prime} \mathrm{S} 132^{\circ} 36.7^{\prime} \mathrm{E}, 28 \mathrm{Apr} 1988$, P. Dostine (NTM); male, ARRS, 5 km W South Alligator River OSS Stn, 19 Apr 
1988, Wells and Suter, $13^{\circ} 33^{\prime} \mathrm{S} 132^{\circ} 34^{\prime} \mathrm{E}$ (NMV); male, Litchfield NP, Walker Creek, 18-19 Apr 1992, Wells (NTM). WA: 2 males, 2 females, Bell Gorge, Melaleuca Hole, $17^{\circ} 01$ 'S $125^{\circ} 14^{\prime} \mathrm{E}$, I. Edwards (NMV).

Diagnosis. Male genitalia, in ventral view, with inferior appendages broad-based, slightly produced apicomedially, lateral lobes almost twice basal section, and tergite $\mathrm{X}$ a simple, broad membranous plate with acute apicolateral angles.

Description. Spurs 1, 2, 2. Forewing length 4.5-5.1 mm. Wings of typical slender shape, neuration variable with forewing fork 1 with a short footstalk (N Qld forms) or sessile (NT form), t1 slightly more distal than $\mathrm{t} 3$ (N Qld) or both $\mathrm{t} 1$ and $\mathrm{t} 3$ well distal of $\mathrm{t} 2$; wing membrane dark along cross veins of posterior anastomosis. Male genitalia, Figs 47-49. Segment IX narrow, preanal appendages short, broad-based, rounded apically. Segment $\mathrm{X}$ broad at base and apex, a wide apicomesal concavity resulting in acute apicolateral processes. Inferior appendages in ventral view broad-based, extending apico laterally as stout short lobes, in lateral view more or less straight but with a basi-ventral notch. Phallus strongly arched in lateral view.

Distribution. South-eastern and northern Qld, northern NT and northern WA (Fig. 116).

Remarks. The forewing venation of $O$. spicata varies from footstalk short on forewing fork 1 (N Qld form) to having fork 1 sessile (NT form), and crossveins of the posterior anasto-mosis varied, as indicated above. However, the males from NE Queensland, N Northern Territory and NW Western Australia show such close similarities in genitalic structures that, tentatively, the differing position of the fork on the forewing is considered simply to be variation within a local population.

Etymology. From Latin spica - point, for the apicolateral processes on segment $X$.

Oecetis crena sp. nov.

Figures 50-52, 117

Material examined. Holotype, male, Vic., Gibbo River at Exhibition Creek junction, $20 \mathrm{~km} \mathrm{~N}$ Benambra, 16 Jan 1982, A. Wells (NMV T-18512)

Paratypes, Vic.: 1 male, 5 females, Mitta Mitta river, $8 \mathrm{~km}$ NE of Benambra, 5 Feb 1974, A. Neboiss (NMV); 1 male, Wellington River, $23 \mathrm{~km}$ NNE of Licola on Tamboritha Road, 21 Feb 1978, NMV Survey Department (NMV); 1 male, Yarra River, East Warburton, ii.1980, I Campbell (NMV); 1 male, 2 females, Nongungarra and Crooked River junction, 4 Feb 1981, J. Blyth (NMV); male, Cobungra River, at Anglers Rest, 15 January 1982, A. Wells (NMV).

Other material. Vic.: male, 4 females, Porepunkah River, 26 Jan 1960, A. Neboiss (NMV).

Diagnosis. Male genitalia inferior appendages clasper-shaped, with a median expansion on the inner margin and fringes of short setae dorso-basally; in the forewing a footstalk on fork 1 , and $\mathrm{t} 2$ more distal than $\mathrm{t} 1$ and $\mathrm{t} 3$.

Description. Spurs 1, 2, 2. Forewing length 7.1-8.1mm. Wings with long downy setae along veins; forewing fork 1 about twice length of footstalk, anterior anastomosis with $\mathrm{t} 1$ and $\mathrm{t} 2$ almost level, more distal than $\mathrm{t} 3$. Male genitalia, Figs 50-52. Segment
IX short, a triangular projection midlaterally on apical margin, preanal appendages small, ovoid, separated. Segment X simple, membranous. Inferior appendages elongate, slender, in ventral view with a medial notch on inner margin; in lateral view a knob dorsally at base, slender and tapered distally. Phallus short, down-turned medially.

Distribution. Eastern Vic. (Fig. 118).

Etymology. Latin, crena - notch or rounded projection.

\section{Oecetis quadrata sp. nov.}

Figures 53-56, 118

Material examined. Holotype, male, North Qld, Zarda Creek nr Mt Misery, W of Mossman, 1200 m, 23 Nov 1974, M.S. Moulds (NMV T-18513).

Other material. Qld: male, Birthday Creek, 6 km NWW Paluma, $18^{\circ} 59^{\prime} \mathrm{S} 146^{\circ} 10^{\prime} \mathrm{E}, 25$ Sep 1980, J.C. Cardale (ANIC).

Diagnosis. $\mathrm{Cu} 1$ and $\mathrm{Cu} 2$ in the hind wing arising at crossvein $\mathrm{m}-\mathrm{cu}$, and preanal appendages exceedingly large, rectangular, free.

Description. Tibial spurs 1, 2, 2. Male forewing length $7.6 \mathrm{~mm}$. Wings (Fig. 53) slender, forewing length about 4 times maximum width, footstalk on fork 1 about as long as fork, posterior anastomosis stepped with $\mathrm{t} 2$ more distal than $\mathrm{t} 1, \mathrm{t} 3$ distad of $\mathrm{t} 1$ and $\mathrm{t} 2$; in hind wing $\mathrm{Cu} 1$ and $\mathrm{Cu} 2$ arise at crossvein $\mathrm{m}-\mathrm{cu}$. Male genitalia, Figs 54-56. Segment IX broad ventrally and laterally, narrow middorsally, preanal appendages large, subquadrate. Segment X membranous, bifid. Inferior appendages broad in basal half, strongly constricted medially, narrow distally. Phallus short, apex strongly down-turned.

Distribution. North-eastern Qld (Fig. 118).

Remarks. When viewed laterally, the genitalic features of $O$. quadrata males generally resemble those of $O$. inscripta. The species has been collected from two disjunct localities only.

Etymology. Latin, quadrata - four-cornered, for the unusual shape of the preanal appendages.

\section{Oecetis dilata sp. nov.}

Figures 57-59, 119

Material examined. Holotype, male,WA, $9 \mathrm{~km} \mathrm{~N}$ of Kununurra, 19 Sep 1979, J. Blyth (NMV T-18514).

Paratypes.WA: 3 males, 2 female, same data as for holotype (NMV); 2 males, Geikie Gorge, $18^{\circ} 06^{\prime} \mathrm{S} 125^{\circ} 42^{\prime} \mathrm{E}, 5$ Oct 1996 , I. Edwards (NMV). Qld: 2 males, female, McLeod River, $15 \mathrm{~km} \mathrm{~W}$ of Mt Carbine, 22-23 Jun 1975, S.R. Monteith (ANIC); 2 males, Cape York Peninsula, Laura, $15^{\circ} 33.9^{\prime}$ S $144^{\circ} 27.1^{\prime}$ E, 7 Oct 1979 , M.S. and B.J. Moulds (NMV); 2 males, 2 females, $11^{\circ} 08^{\prime S} 142^{\circ} 21^{\prime} \mathrm{E}$, Jardine River, 19 Oct 1992, P. Zborowski and T. Weir (ANIC). NT: 2 males, Daly River, $13^{\circ} 45^{\prime} \mathrm{S} 132^{\circ} 42^{\prime} \mathrm{E}, 9-10$ Aug 1980 , M.B. Malipatil (NMV).

Diagnosis. Forewing length about 4 times maximum width, footstalk present on fork $1, \mathrm{t} 1$ more distal than $\mathrm{t} 2$ or $\mathrm{t} 3$. Males genitalic features, inferior appendages, in ventral view have width about 0.75 times length, and are rounded towards the 

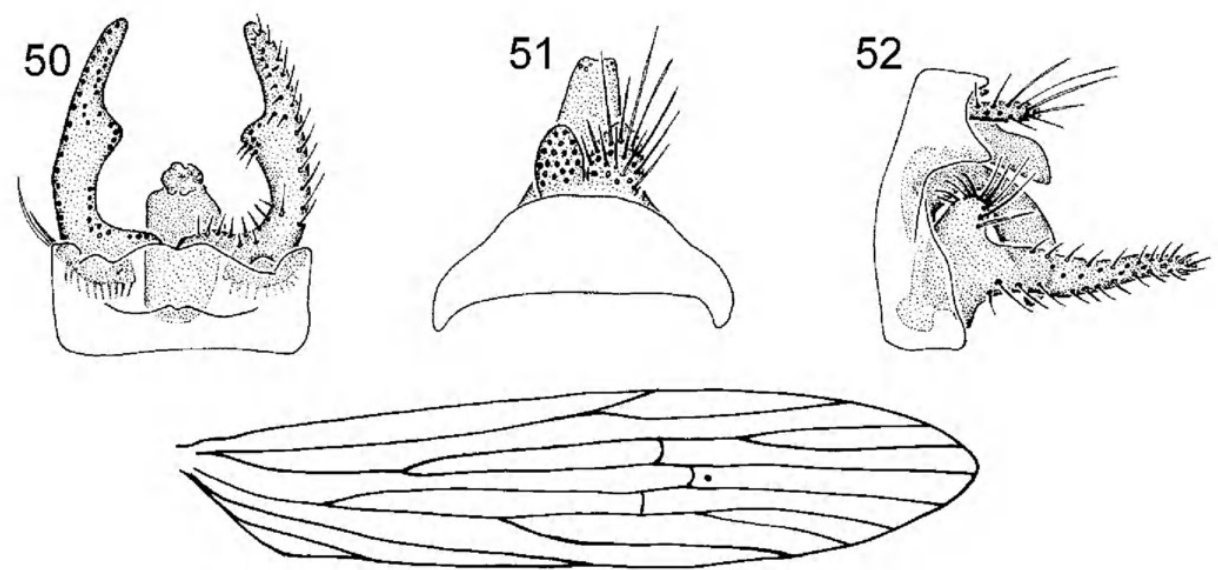

53

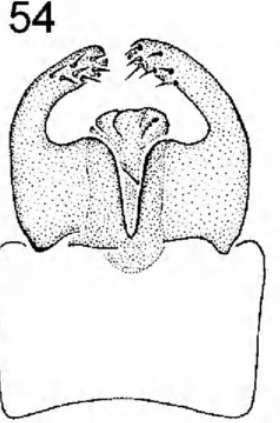

57

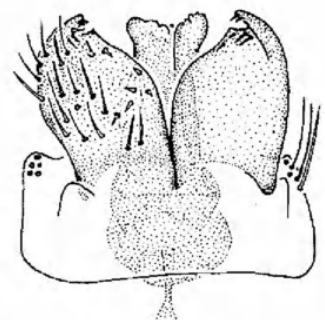

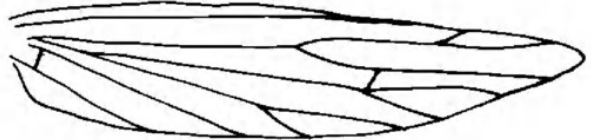
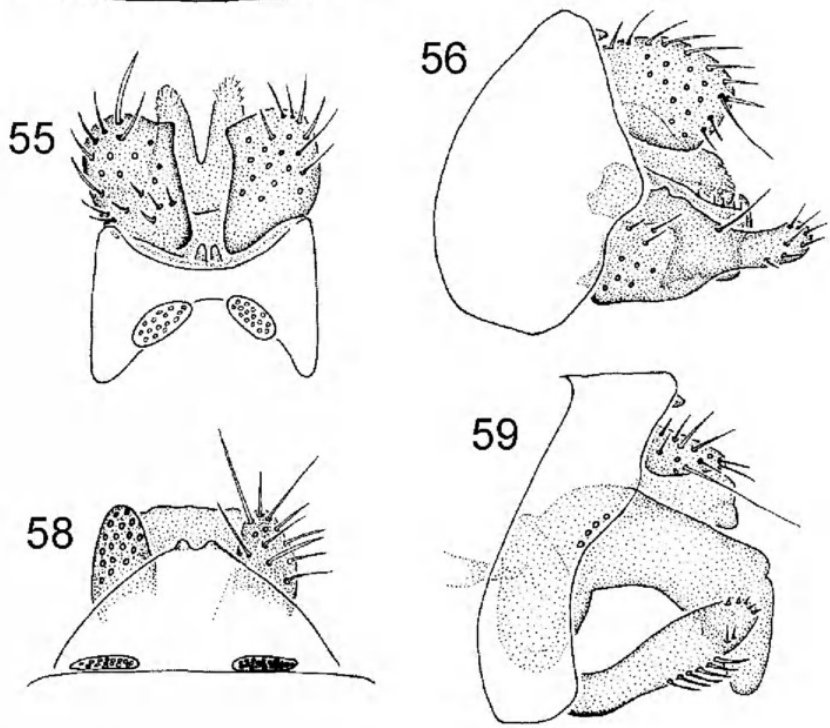

Figures 50-52, Oecetis crena sp. nov., male genitalia, ventral, dorsal and lateral views.

Figures 53-56, O. quadrata sp. nov.: 53, fore- and hind wings; 54-56, male genitalia, ventral, dorsal and lateral views.

Figures 57-59, $O$. dilata sp. nov., male genitalia, ventral, dorsal and lateral views.

apex, with a small apicolateral lobe, and in lateral view, have length about 4 times width.

Description. Spurs 1, 2, 2. Male forewing length 4.8-5.4 mm. Forewing with footstalk on fork 1 slightly shorter than fork; posterior anastomosis stepped with $\mathrm{t} 1$ more distal than $\mathrm{t} 2, \mathrm{t} 3$ oblique, slightly distad of t2. Male genitalia, Figs 57-59. Segment IX uniformly narrow, preanal appendages ovoid, widely separated. Segment X simple broad, apically truncate. Inferior appendages stout, apically rounded with short, thin lobe laterally; narrow and straight in lateral view, rounded apically. Phallus stout, rounded, strongly curved downwards.

Distribution. Far northern Qld, NT and WA (Fig. 119).

Etymology. Latin, dilata - enlarge, for the unusually broad inferior appendages.
Oecetis koobarra sp. nov.

Figures 60-63, 120

Oecetis sp. 'H' —Wells 1991: fig. 139.

Material examined. Holotype, male, NT, Kakadu National Park, Radon Creek, 3 Sep 1979, J. Blyth (NTM).

Paratypes. NT: 15 males, ARRS, Radon Springs, 13/14 Apr 1988, Suter and Wells (NTM and NMV); male, Magela Creek, 7 Apr 1993, P. Dostine (NTM).

Other material. NT: male, 3 females, $12^{\circ} 50^{\prime} \mathrm{S} 132^{\circ} 51^{\prime} \mathrm{E}, 16 \mathrm{~km}$ EbyN of Mt Cahill, 13 Jun 1973, J.C. Cardale (ANIC); male, $12^{\circ} 48^{\prime} \mathrm{S}$ $132^{\circ} 49^{\prime} \mathrm{E}$, Kakadu National Park, Baroalba Springs, 16 Jan 1992, Wells and Webber (NTM); pupa, Litchfield National Park, Walker Creek, 18 Apr 1992, A. Wells (NMV); 2 males, Litchfield National Park, Walker Creek, 18/19 Apr 1992, A. Wells (NMV); 4 males, $12^{\circ} 48^{\prime} \mathrm{S} 132^{\circ} 49^{\prime} \mathrm{E}$, Kakadu National Park, 

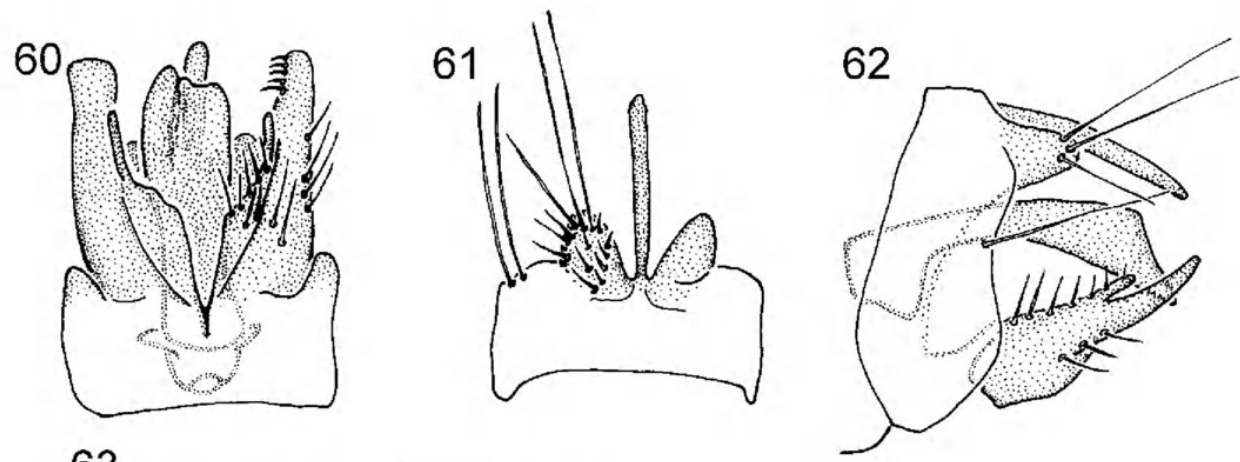

63

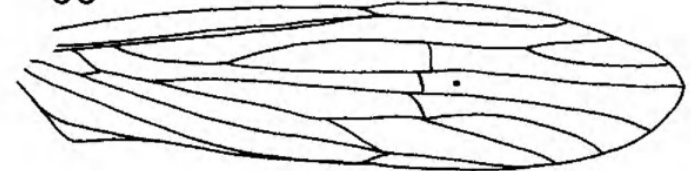

64
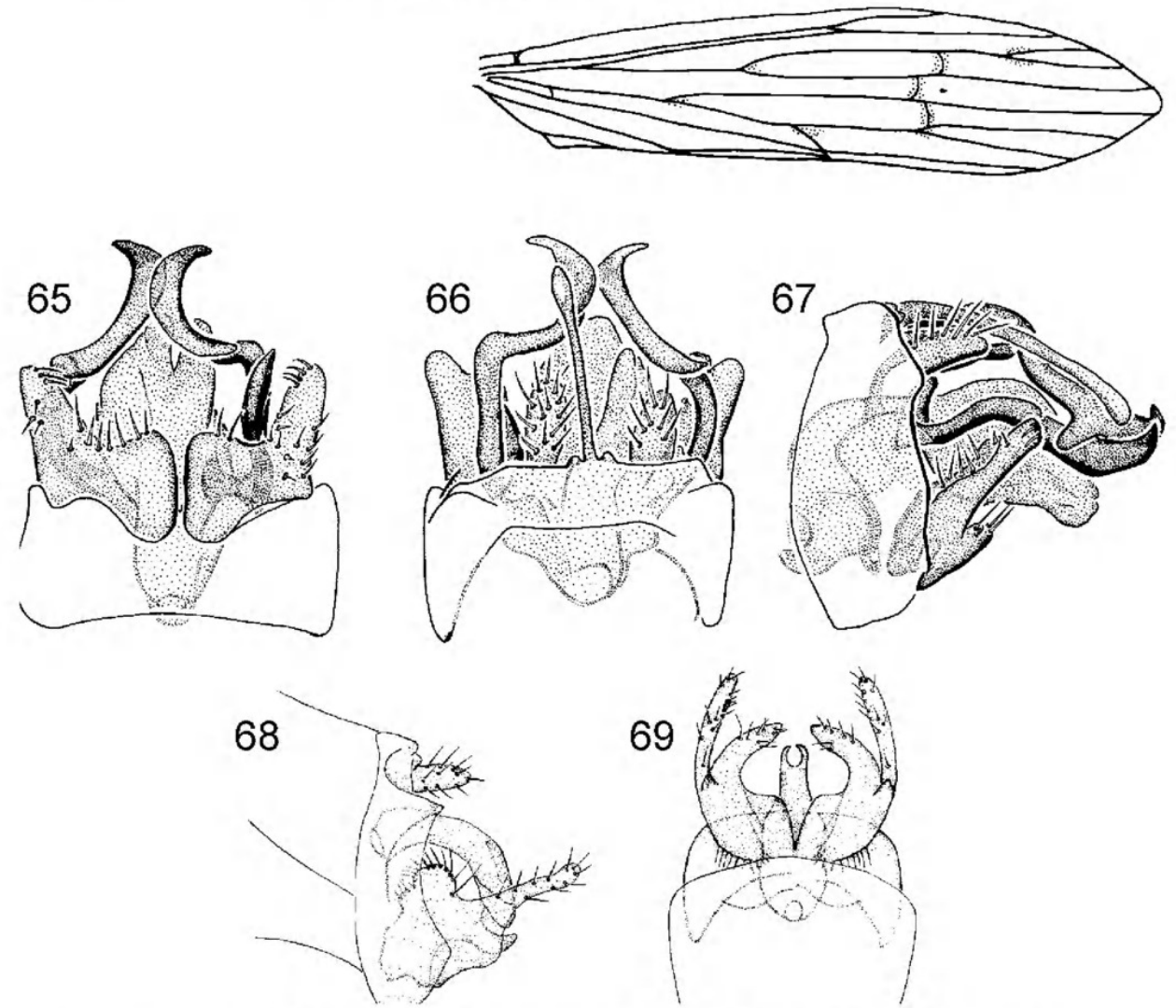

Figures 60-63, Oecetis koobarra sp. nov.: 60-62, male genitalia, ventral, dorsal and lateral views; 63, forewing. Figures 64-67, $O$. falcata sp. nov.; 64, forewing; 65-67, male genitalia in ventral, dorsal and lateral views.

Figures 68, 69, O. terania sp. nov., male genitalia in lateral and ventral views.

Baroalba Springs, 25 Apr 1991, Wells and Webber (NTM); 3 males, 1 female, $12^{\circ} 48^{\prime} \mathrm{S} 132^{\circ} 49^{\prime} \mathrm{E}$, Kakadu National Park, Baroalba Springs, 29 May 1991, Wells and Webber (NTM); male, Melville Island, $11^{\circ} 36$ 'S $130^{\circ} 43^{\prime} \mathrm{E}, 4$ Oct 1996, G.R. Brown (NTM); male, Melville Island, nr Pickertaramoor, $11^{\circ} 46$ 'S $130^{\circ} 53^{\prime} \mathrm{E}, 10$ Oct 1996, G.R. Brown (NTM).

Diagnosis. Dark zig-zag mark on forewing (Fig. 63) formed by pattern on wing membrane around the stepped posterior anastomosis; overall straight-sided male genitalia, phallus narrow mesially, with apex obliquely truncate.
Description. Tibial spurs 1, 2, 2. Male forewing length 4.6-5.6 $\mathrm{mm}$. Wing laminae with vestiture of equal length; forewing (Fig. 63) with a zig-zag pattern marking posterior anastomosis, a footstalk on fork $1, \mathrm{t} 1$ more distal than $\mathrm{t} 2, \mathrm{t} 2$ and $\mathrm{t} 3$ contiguous. Male genitalia, Figs 60-62. Segment IX almost uniform in length all round, preanal appendages well separated, ovoid. Segment $\mathrm{X}$ with long, slender dorsal process. Inferior appendages straight-sided, stepped in midlength on inner margin, and with a slender dorsal lobe at midlength. Phallus in lateral view slender medially, obliquely angled towards apex. 
Distribution. Northern NT (the 'Top End'), and offshore Melville Island in the Tiwi Islands Group (Fig. 120).

Remarks. Oecetis koobarra is distinctive for both its wing markings and its very angular male genitalia. It is probably most closely allied to $O$. parka. An associated pupa is from a cornucopia-shaped sand case.

Etymology. Koobarra, now the official name for Baroalba Springs, one of the collecting localities.

\section{Oecetis falcata sp. nov.}

Figures 64-67, 121

Material examined. Holotype, male, Upper Jardine River, Cape York, Qld, $11^{\circ} 14^{\prime}$ 'S $142^{\circ} 36^{\prime} \mathrm{E}, 26$ Oct 1979, M.S. and B.J. Moulds (NMV T-18515).

Paratypes. Qld: 72 males, females, same data as for holotype (NMV, ANIC).

Other material. Qld: male, female, Iron Range, Cape York Pen., 2- Jun 1971, E.F. Riek (ANIC); male, female, Mt Molloy, 13 Jun 1971, E.F. Riek (ANIC); male, 2 females, Iron Range, West Claudie River, 17 Sep 1974, Moulds (NMV); male, Iron Range, Middle Claudie River, 2-9 Oct 1974, Moulds (NMV); male, Jardine River, Cape York, $11^{\circ} 09^{\prime}$ S $142^{\circ} 27^{\prime} \mathrm{E}, 11$ Oct 1979 , M.S. and B.J. Moulds (NMV); 7 males, 4 females, Jardine River, Cape York, $11^{\circ} 08^{\prime} \mathrm{S} 142^{\circ} 35^{\prime} \mathrm{E}$, 14 Oct 1979, M.S. and B.J. Moulds (NMV); 3 males, Jardine River, Cape York, $11^{\circ} 17^{\prime} \mathrm{S} 142^{\circ} 35^{\prime} \mathrm{E}, 17$ Oct 1979 , M.S. and B.J. Moulds (NMV); 8 males, 2 females, Jardine River, Cape York, $11^{\circ} 19^{\prime} \mathrm{S}$ $142^{\circ} 37^{\prime}$ E, 22 Oct 1979, M.S. and B.J. Moulds (NMV); 2 males, Jardine River, Cape York, $11^{\circ} 14^{\prime}$ S $142^{\circ} 36^{\prime} \mathrm{E}, 24$ Oct 1979, M.S. and B.J. Moulds (NMV); male, Qld, Tributary of Bertie Creek, $250 \mathrm{~m} \mathrm{SW}$ of Heathlands HS, $11^{\circ} 45^{\prime} \mathrm{S} 142^{\circ} 35^{\prime} \mathrm{E}, 11 \mathrm{Feb} 1992$, Cartwright and Wells, $11^{\circ} 45^{\prime} \mathrm{S} 142^{\circ} 35^{\prime} \mathrm{E}(\mathrm{QM})$ (slide); 3 males, 1 female, Cape York Peninsula, Pascoe River crossing (to Iron Range), 4.10.2002, G. Theischinger (ANIC); 6 males, 7 females, Cape York Peninsula, Dul-hunty River crossing at Telegraph rd, 7.10.2002, G. Theischinger (ANIC).

Diagnosis. Forewing length about 4 times maximum width, footstalk on fork 1 almost equal in length to the fork. In the male genitalia, a pair of asymmetrical,scythe-like, sclerotised processes dorsally, one at each side of the phallus

Description. Spurs 1, 2, 2. Male forewing length 4.1-5.2 mm. Wings (Fig. 64): forewing with patches of dark membrane at crossveins of posterior anastomosis and, more proximally, triangles of dark membrane at several forks; narrow, tapered distally; footstalk on fork 1 equal in length to fork; $\mathrm{t} 1$ and $\mathrm{t} 3$ at about same level in wing, $\mathrm{t} 2$ more proximal. Male genitalia, Figs 65-67. Abdominal segment IX narrow, but broader than in $O$. ancala. Preanal appendages about twice as long as wide. Tergite X very slender, reaching almost to length of other genitalic parts. Inferior appendages in ventral view broadbased, laterally produced to about twice length of basal section, in lateral view more slender. Phallus broad. Dorsolateral processes unequal, the left one twisted in basal half, curved outwards in distal half, right one more or less that same shape, but less twisted.

\section{Distribution. Far northern Qld (Fig. 121).}

Remarks. As with $O$. ancala, grouping of this species is equivocal, as the homologies of the processes are uncertain.
Etymology. Latin, falcata - sickle-shaped, for the shape of the lateral processes.

\section{Oecetis terania sp. nov.}

Figures 68, 69, 122

Material examined. Holotype, male, NSW, Terania Creek, N of Lismore, $28^{\circ} 25^{\prime} \mathrm{S} 153^{\circ} 18^{\prime} \mathrm{E}$, 21 Jan 1986, G. Theischinger (NMV $\mathrm{T}-18516)$ (slide).

Paratypes. 2 males, 1 female, same data as holotype (NMV) (one male on slide).

Diagnosis. Wings with dense vestiture of downy hair and male genitalia with inferior appendages bifurcate in lateral half, the ventral lobes curving and clasper-like, the dorsal lobes more slender and straight.

Description. Spurs 1, 2, 2. Male forewing length 6.0-6.1 mm. Wings typical form, tapered distally; footstalk on fork 1 about half length of fork; $\mathrm{t} 2$ more distal than $\mathrm{t} 1$ or $\mathrm{t} 3$. Genitalia, Figs 68,69 . Abdominal segment IX narrow. Preanal appendages discrete, about twice as long as wide in lateral view, more or less conical in dorsal view. Tergite $\mathrm{X}$ a short, narrow membrane, about length of preanal appendages. Inferior appendages in ventral view broad-based, bilobed in distal half, with the ventral lobes almost meeting mesially, dorsal arms slender and straight; in lateral view stout and irregular in shape basally, the dorsal arm almost straight, extending well beyond the ventral arm. Phallus curved ventrally.

Distribution. North-eastern NSW (Fig. 122).

Remarks. In shape the male inferior appendages of this species more closely resembles those of some complexa-group species, but the phallus lacks spines or parameres of the kind seen in that group. The species is known only from the type locality.

Etymology. For the creek at the collecting site.

\section{Oecetis papposa sp. nov.}

Figures 70-73, 123

Material examined. Holotype, male, NT, South Alligator River, UDP Falls [Gunlom], $13^{\circ} 24.9^{\prime} \mathrm{S} 132^{\circ} 26.0^{\prime} \mathrm{E}, \mathrm{J}$. Blyth (NMV T-18517).

Paratypes. NT: male, Jim Jim Creek, $3 \mathrm{~km}$ below falls, Kakadu National Park, 1 Sep 1979, J. Blyth (NMV); male, Katherine River Gorge National Park, 13 Aug 1979, J. Blyth (NMV); male, ARRS Creek $5 \mathrm{~km}$ W of OSS South Alligator field station, 19 Apr 1989, Wells and Suter (NMV); 6 males, ARRS, Radon Springs, 13-14 Apr 1989, Suter and Wells (NTM); 1 male, $12^{\circ} 42^{\prime} \mathrm{S} 132^{\circ} 57^{\prime} \mathrm{E}$, Kakadu National Park, Magela Creek, OSS Site 009, 15 Mar 1991, Wells and Webber (NTM); male, $12^{\circ} 48^{\prime}$ S $132^{\circ} 49^{\prime} \mathrm{E}$, Baroalba Springs, 4 Apr 1991, Wells and Webber (NTM); male, $12^{\circ} 48^{\prime} \mathrm{S} 132^{\circ} 49^{\prime} \mathrm{E}$, Baroalba Springs, 16 Aug 1991, Wells and Webber (NTM); 4 males, 2 females, $12^{\circ} 48^{\prime} \mathrm{S}$ $132^{\circ} 49^{\prime} \mathrm{E}$, Baroalba Springs, 25 Apr 1991, Wells and Webber (NTM); 2 males, female, $12^{\circ} 48^{\prime} \mathrm{S} 132^{\circ} 49^{\prime} \mathrm{E}$, Baroalba Springs, 4 Oct 1991 , Wells and Webber (NTM).

Other material. NT: male, Litchfield National Park, Florence Falls, $13^{\circ} 03^{\prime} \mathrm{S} 130^{\circ} 47^{\prime} \mathrm{E}, 9 \mathrm{Apr} 1991$, Wells and Horak (NMV); 4 males, $12^{\circ} 48^{\prime} \mathrm{S} 132^{\circ} 49^{\prime} \mathrm{E}$, Baroalba Springs, 16 Jan 1992, Wells, Webber and Bickel (NTM); male, Litchfield National Park, Walker Creek, 18-19 Apr 1992, A. Wells (NTM).WA: 4 males, Drysdale River headwaters, 30 km NW Mt Elizabeth H.S., 30 Sep 1979, J. Blyth (NMV); 9 males, 

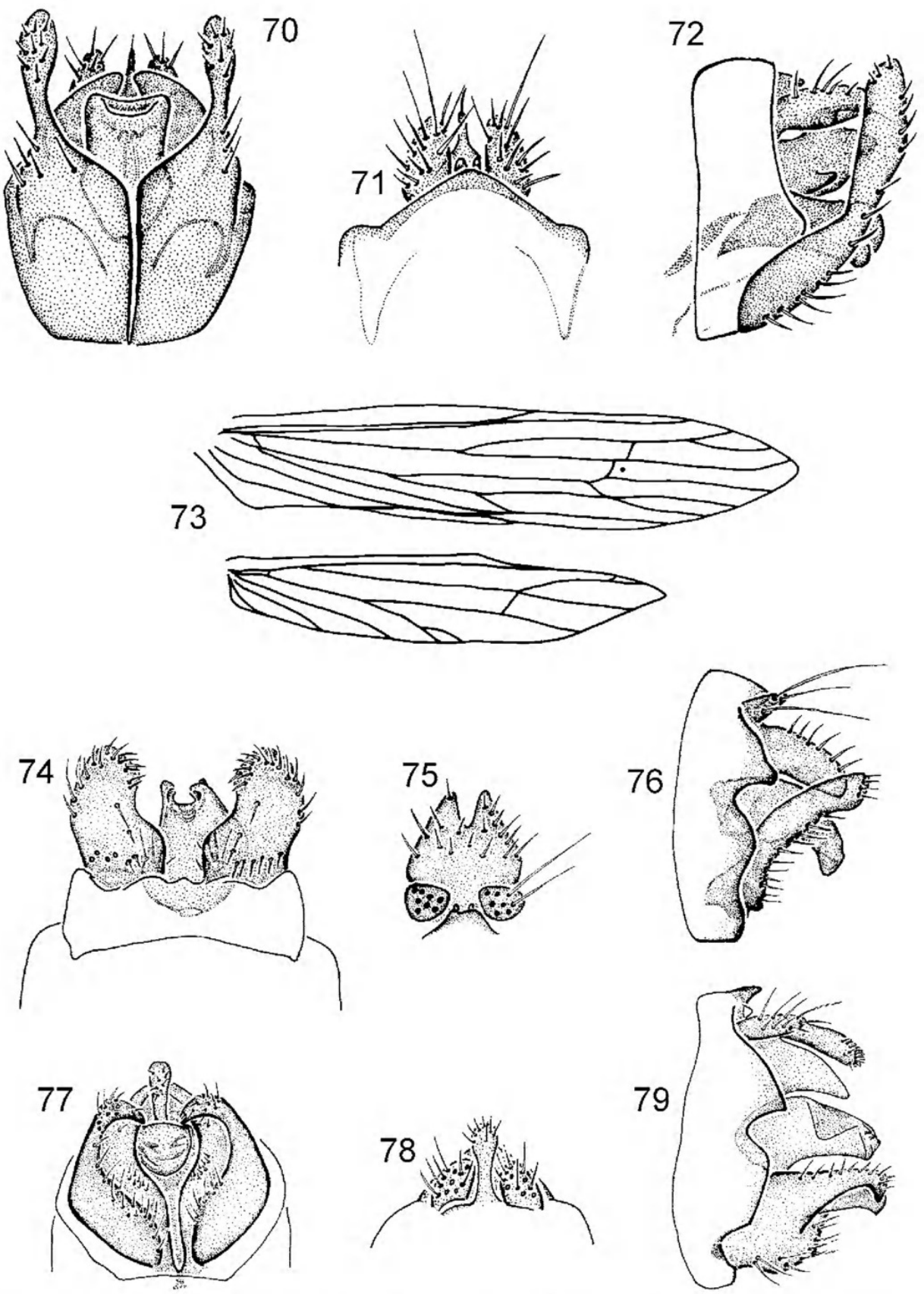

Figures 70-73, Oecetis papposa sp. nov.: 70-72, male genitalia in ventral, dorsal and lateral views; 73, fore- and hind wings. Figures 74-76, $O$. curta sp. nov., male genitalia, ventral, dorsal and lateral views.

Figures 77-79, O. aduncata sp. nov.: male genitalia, ventral, dorsal and lateral views.

King Edward River, $14^{\circ} 54^{\prime}$ S $16^{\circ} 12^{\prime} E$, 3 Sep 1996, I. Edwards (NMV); 6 males, Pearson's Creek S edge of Prince Regent Res., $16^{\circ} 01^{\prime} \mathrm{S} 125^{\circ} 35^{\prime} \mathrm{E}, 5$ Sep 1996, I. Edwards (NMV); males, females, Drysdale River upper reaches, $16^{\circ} 09^{\prime} \mathrm{S} 125^{\circ} 58^{\prime} \mathrm{E}, 7$ Sep 1996, I. Edwards (NMV); males, females, Manning River nr Mt Barnett, $16^{\circ} 40^{\prime} \mathrm{S} 125^{\circ} 56^{\prime} \mathrm{E}, 8$ Sep 1996, I. Edwards (NMV).

Diagnosis. Hindwing vein M unbranched; in male genitalia, short, straight phallus and elongate inferior appendages with a strong medial constriction.
Description. Spurs 0, 2, 2. Wings (Fig. 73) narrow, length over 4 times maximum width, with downy hair (readily lost in preserved specimens). Male forewing length 4.2-5.4 $\mathrm{mm}$. Forewing with footstalk on fork 1 of variable length, less than or equal to length of fork; posterior anastomosis in part obliquely linear, $\mathrm{t} 3$ more proximal than $\mathrm{t} 1$ and $\mathrm{t} 2$. Hind wing with venation strongly reduced, $M$ unbranched. Maxillary palps very long, all segments of equal length. Male genitalia, Figs 70-72. Segment IX excavated midventrally, preanal 
appendages elongate-ovate, separated. Segment $\mathrm{X}$ in form of a pair of stout, membranous lobes, with setate, digitiform mesal process. Inferior appendages in ventral view broadbased, slender distally, slightly dilated towards apices, in lateral view, slender but constricted medially. Phallus short, straight, with only a slight apicoventral lip.

Distribution. Northern NT and northern WA (Fig. 123).

Etymology. From Latin, pappus — hair, for the hairy wings.

Oecetis curta sp. nov.

Figures 74-76, 124

Material examined. Holotype. Male, Qld, Girraween National Park, nr Wyberba, 10 Oct 1973, A. Neboiss (NMV T-18518).

Paratypes. Qld: male, same data as for holotype; 1 male, Mothar Mtn, $32 \mathrm{~km}$ SE of Gympie, 29 Oct 1980, A. Neboiss (NMV); male, Cape York Pen, Laura, $15^{\circ} 33.9^{\prime}$ S $144^{\circ} 27.1^{\prime} \mathrm{E}, 7$ Oct 1979 , M.S. and B.J. Moulds (NMV). NSW: 3 males, female, $48 \mathrm{~km} \mathrm{~N}$ of Singleton, 'Tuglo' alt. 760 m, 5 Oct 1975, M.S. Moulds; (NMV); 16 males, 4 females, Terania Creek, $\mathrm{N}$ of Lismore, $28^{\circ} 25^{\prime} \mathrm{S} 153^{\circ} 18^{\prime} \mathrm{E}, 21$ Jan 1986 , G. Theischinger (NMV); 6 males, female, Wilson River, NW of Wauchope, $31^{\circ} 14^{\prime} \mathrm{S} 152^{\circ} 34^{\prime} \mathrm{E}, 30$ Oct 1981 , Wells and Carter (NMV).

Diagnosis. Wings uniformly fuscous to mottled; forewing without footstalk on fork 1 . In male genitalia, tergite $\mathrm{X}$ covered with short setae and shallowly cleft apically; inferior appendages elongate and straight to slightly curved in lateral view.

Description. Spurs 1, 2, 2. Male forewing length 6.6-8.6 mm. Wings rounded apically, hair along veins long, downy in appearance, forewing fork 1 sessile or with a very short footstalk; $\mathrm{t} 1$ more distal than $\mathrm{t} 2$ and $\mathrm{t} 3$ which are almost contiguous, all three crossveins marked by darkened membrane. Male genitalia, Figs 74-76. Segment IX with lateral cleft, preanal appendages small, rounded, widely separated. Segment X robust and setate, cordate but with apex cleft. Inferior appendages stout, in ventral view separated basally, rounded apically, uniformly stout along length; in lateral view slender, apically obliquely truncate. Phallus short, rounded in ventral view, in lateral view down-turned distally.

Distribution. Eastern NSW, and south-eastern and far northern Qld (Fig. 124).

Remarks. The unusual, hairy segment $\mathrm{X}$ may represent the medial process of segment $\mathrm{X}$ such as is seen in $O$. aduncata or $O$. minasata, but expanded. A similar plate is seen in $O$. cepaforma, but that species has setae only distally, and is not cleft apically.

Etymology. Latin, curta - short, for the phallus.

Oecetis aduncata sp. nov.

Figures 77-79, 125

Material examined. Holotype, male, NSW, Boonoo Boonoo River, 10 $\mathrm{km}$ upstream of falls, $28^{\circ} 37.9^{\prime} \mathrm{S} 152^{\circ} 15.1^{\prime} \mathrm{E}, 31$ Oct 1975 , A. Neboiss (NMV T-18519) (slide).

Paratypes. NSW: 1 male, Bargo River, $10 \mathrm{~km} \mathrm{SW}$ of Picton, $34^{\circ} 14.9^{\prime} \mathrm{S} 150^{\circ} 34.0^{\prime \prime E}, 30$ Dec 1977, A. Neboiss (NMV). Vic: 1 male, Watson's Creek, $37^{\circ} 42^{\prime} \mathrm{S} 145^{\circ} 16^{\prime} \mathrm{E}, 16$ Dec 1951, A. Neboiss (NMV);
1 male, Yae River, $7 \mathrm{~km} \mathrm{~S}$ of Glenburn, $37^{\circ} 25.4^{\prime} \mathrm{S} 145^{\circ} 25.3^{\prime} \mathrm{E}, 1 \mathrm{Dec}$ 1972, A. Neboiss (NMV); 1 male, Belles Clearing, 6 km S of Aberfeldy, 37³9.7'S $146^{\circ} 26.4^{\prime} \mathrm{E}, 8 \mathrm{Feb} 1977$, T131, A.A. Calder (NMV) (slide); 1 male, Gibbo River, Exhibition Creek, $20 \mathrm{~km} \mathrm{~N}$ of Benambra, 36 44.6'S $147^{\circ} 44.4^{\prime} \mathrm{E}$, 16 Jan 1982, A. Wells (NMV) (slide).

Other material. Qld: 1 male, Tewah Creek, Tin Can Bay, 2548.9'S $153^{\circ} 1.0^{\prime} \mathrm{E}, 17-18$ Oct 1971, S.R. Monteith (ANIC); 2 males, The Crater, nr Herberton, $25^{\circ} 2.9^{\prime} \mathrm{S} 148^{\circ} 24.1^{\prime} \mathrm{E}, 18 \mathrm{Dec} 1974$, M. Moulds (slides) (NMV); 3 males, $15^{\circ} 17^{\prime} \mathrm{S} 145^{\circ} 10^{\prime} \mathrm{E}, 5 \mathrm{~km}$ WbyN Rounded Hill nr Hope Vale Mission, 7 Oct 1980, J.C. Cardale (ANIC); 2 males, $15^{\circ} 47^{\prime} \mathrm{S} 145^{\circ} 17^{\prime} \mathrm{E}$, Moses Creek, Finnigan, 14 Oct 1980, J.C. Cardale (ANIC).

Diagnosis. Fork 1 in forewing sessile and wings mottled. In forewing, $\mathrm{t} 1$ more distal than $\mathrm{t} 2$ or $\mathrm{t} 3$; in male genitalia, inferior appendages broad and strongly ridged along their length, in lateral view with tips sharply down-turned and phallus in lateral view appearing as if it has a triangular fold subapically.

Description. Spurs 1, 2, 2. Male forewing length 6.1-7.1 mm. Wings tapered apically; forewing fork 1 sessile, posterior anastomosis obliquely stepped, t1 more distal than other two crossveins. Male genitalia, Figs 77-79. Segment IX with apical margin excavated midventrally and midlaterally, preanal appendages, small, well separated, ovate. Segment X broad, membranous, in lateral view broad and down-curved, medial process club-shaped. Inferior appendages appear to be slender and strongly in-turned apically, but are actually broad and deeply ridge, in lateral view broad-based, tapered distally and down-turned apically. Phallus short, simple, down-turned, in lateral view always with a more or less triangular area dorsolaterally before apex.

Distribution. Eastern Australia, from eastern Vic. to southeastern Qld (Fig. 125).

Etymology. Latin, aduncata - bent inwards, for the shape of the inferior appendages.

\section{Oecetis ornata Kimmins, 1962}

Figures 80-83, 126

Oecetis ornata Kimmins, 1962: 157-158.

Material examined. Holotype. Male, Humbolt Bay, Dutch New Guinea [Irian Jaya] (BMNH).

Male, Qld, 3 km ENE Mt Tozer, 1244'S 143ํ1', 2 Jul 1986, J.C. Cardale (ANIC).

Diagnosis. Forewing (Fig. 80) strongly and coarsely patterned, with dark brown markings on the proximal two-thirds. In forewing fork 2 sessile; in male genitalia, phallus with a sclerotised digitate process subapically on ventral side.

Remarks. The single male specimen available for study varies slightly from the type as illustrated by Kimmins (1962). However, given the proximity to New Guinea of the collecting locality in far northern Qld and that the species was described from a single male, the specimen is referred to $O$. ornata for the present. Differences are mainly genitalic - shape of the preanal lobes and of the inferior appendages in lateral view. Figures drawn from the Australian specimen are provided for comparisons (Figs 81-83). 
80
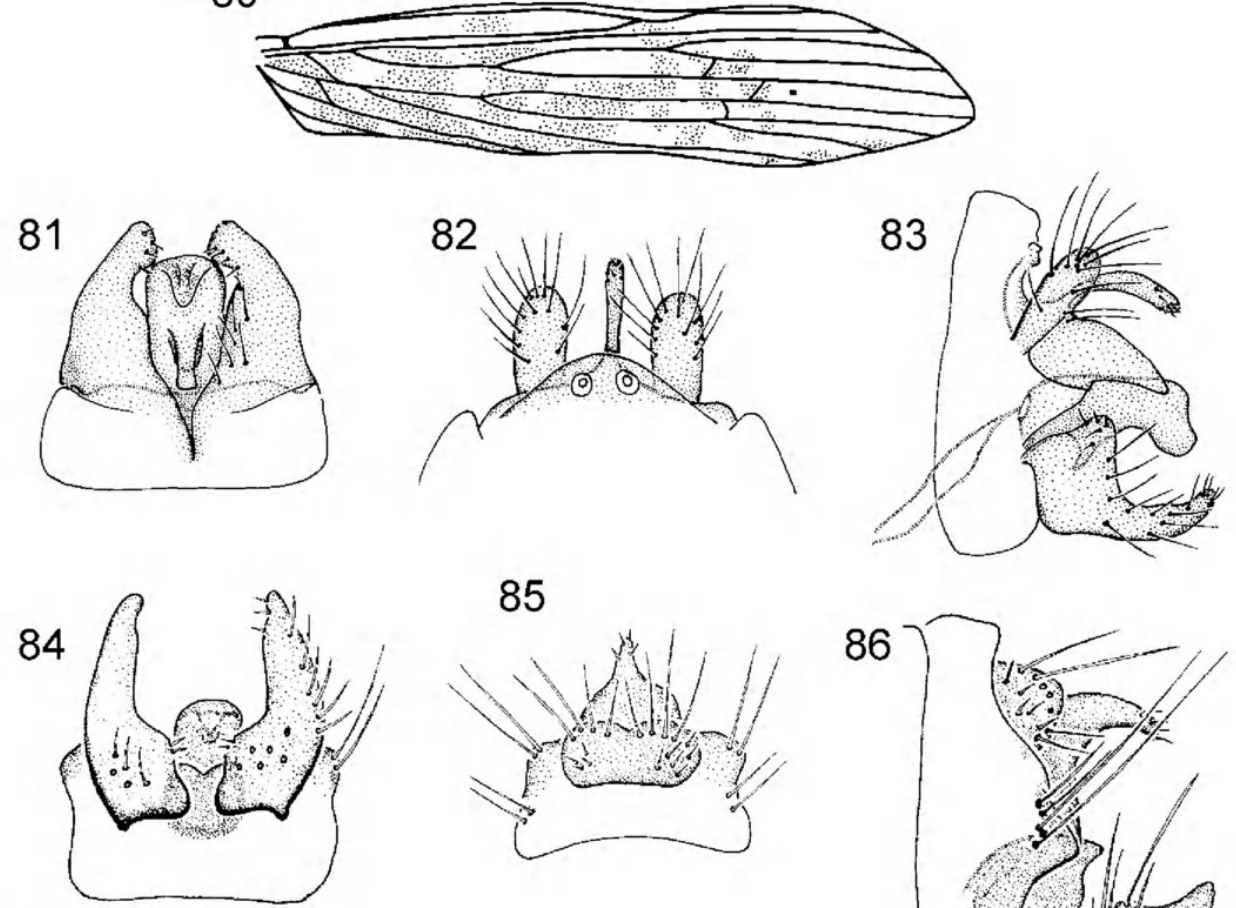

\section{5}
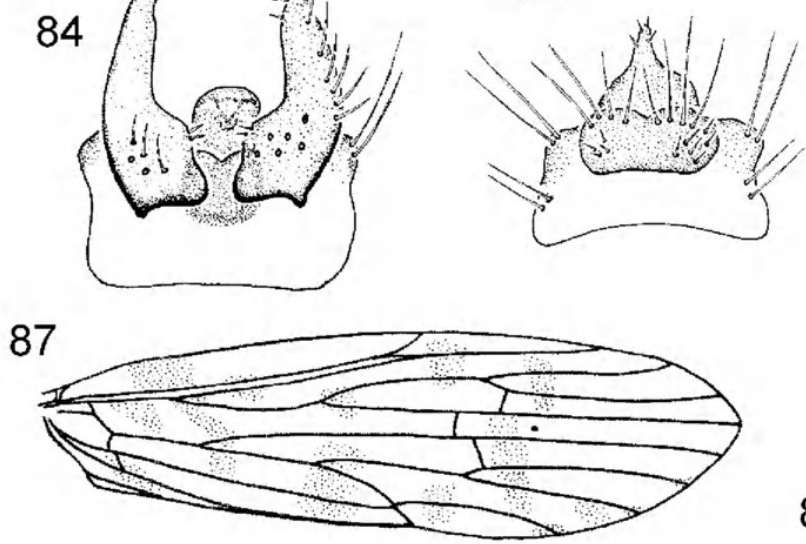

88
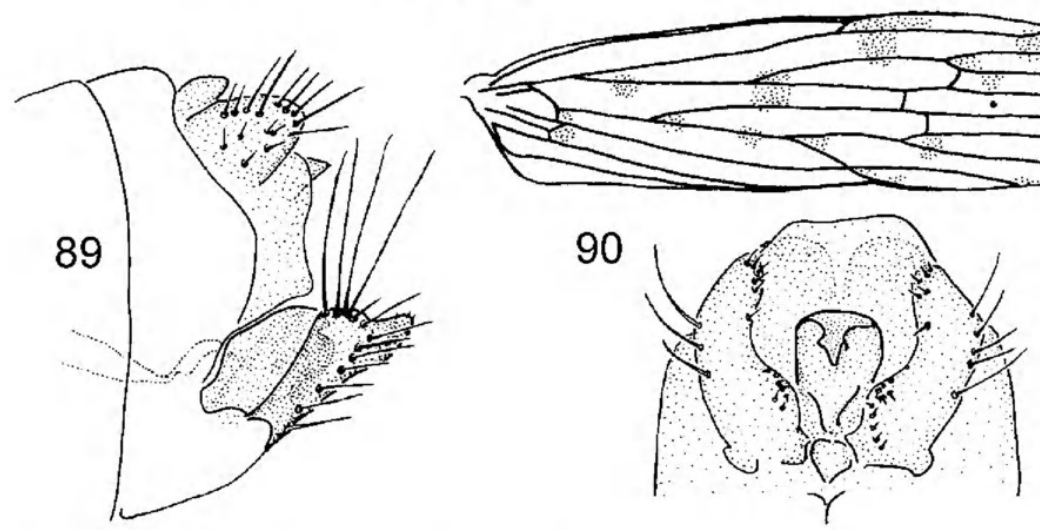

Figures 80, O. ornata Kimmins, forewing (drawn from Australian specimen).

Figures 81-83, Oecetis ornata Kimmins: 79-81, male genitalia, ventral, dorsal and lateral views (drawn from Australian specimen). Figures 84-87, O. cepaforma sp. nov.: 84-86, male genitalia, ventral, dorsal and lateral views; 87 , forewing.

Figures 88-90, O. dostinei sp. nov.: 88, forewing; 89, 90, male genitalia, ventral, dorsal and lateral views.

Distribution. New Guinea and far northern Qld (Fig. 126).

\section{Oecetis cepaforma sp. nov.}

Figures 84-87, 127

Oecetis sp. D.-Wells, 1991: 61 (in key).

Material examined. Holotype. Male, Qld, Erwin Falls on Eliot Creek, $100 \mathrm{~km} \mathrm{~S}$ of Bamaga, 7 Nov 1988, K. Walker (NMV T-18520) (slide).

Paratypes. NT: male, Radon Springs, 13-14 Apr 1989, Suter and Wells (NTM); 2 males, female, same locality and collectors, 18-19
May 1988 (NTM); 2 males, 1 female, same locality and collectors, 14 Apr 1989 (NTM); 1 male, 12 $31^{\circ} \mathrm{S} 132^{\circ} 54^{\prime} \mathrm{E}, 9 \mathrm{~km} \mathrm{~N}$ by $\mathrm{E}$ of Mudginberri HS, 10-11 Jun 1973, J.C. Cardale (ANIC);

Other material. 35 samples in ANIC, NMV, NTM and QM.

Diagnosis. Forewing broad, length scarcely 3 times maximum width, spotted and moth-like, footstalk on fork 1 sessile. In male genitalia inferior appendages with length about 4 times width, a small spur on the baso-mesial angle; tergite $\mathrm{X}$ extended to an elongate-triangular apex, tipped with several short setae. 
Description. Spurs 1, 2, 2. Male forewing length 5.5-5.7 mm. Wings, broad, forewing (Fig. 87) with fork 1 sessile and with large dark spots extending across membrane away from veins; posterior anastomosis stepped, $\mathrm{t} 1$ more distal than $\mathrm{t} 3$ which is more distal than $\mathrm{t} 2$. Male genitalia, Figs 84-86. Segment IX widest midlaterally, preanal appendages large, broadly rounded laterally, fused medially. Segment X onion-shaped in outline in dorsal view, without medial process. Inferior appendages clasper-shaped, widely separated at bases, narrower distally beyond a mesial angle bearing a spur and a cluster of short setae; in lateral view with a medial notch dorsally. Phallus very short.

Distribution. Qld, NT and WA (Fig. 127).

Remarks. The soft, broad, spotted wings give this species a truly moth-like appearance. The male genitalia vary as follows: specimens from northern Qld have the inferior appendages more slender than those from NT, with the several setae at the meso-basal angle shorter and stouter. Larvae build cornucopia-shaped sand grain cases.

Etymology. Latin for onion- or minaret-shaped - cepaforma, being descriptive of the shape of segment X,

\section{Oecetis dostinei sp. nov.}

Figures 88-90, 128

Oecetis sp. G.-Wells, 1991: fig. 144.

Material examined. Holotype male, Qld, Mulgrave River W of Gordonvale, $17^{\circ} 13.9^{\prime} \mathrm{S} 145^{\circ} 57.1^{\prime} \mathrm{E}, 29$ Apr 1979, A. Wells (NMV T-18521, slide).

Paratypes. Qld: male, data as for holotype (NMV) (slide); male,

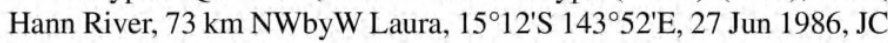
Cardale (ANIC). NT: male, female, UDP Falls [Gunlom], $13^{\circ} 24.9^{\prime} \mathrm{S}$ $132^{\circ} 26.0^{\prime} \mathrm{E}, 18-19 \mathrm{Jul} 1980$, MB Malipatil (NTM); male, ARRS South Alligator River at Gimbat OSS Stn, $13^{\circ} 34.3^{\prime} \mathrm{S} 132^{\circ} 36.7^{\prime} \mathrm{E}, 24$ Mar 1988, Wells and Suter (NMV); 2 males, same loc., 28 Apr 1988, P. Dostine (NTM); male, Litchfield National Park, $13^{\circ} 03^{\prime} \mathrm{S} 130^{\circ} 47^{\prime} \mathrm{E}$, 6 Jun 1991, Wells and Webber (NTM); male, Butterfly Gorge, Katherine River Gorge National Park, 27 Jan 1977. M.S. and B.J. Moulds (NMV).

Diagnosis. Forewing length scarcely 4 times maximum width, spotted and moth-like, but with wing markings on the forewing smaller than in $O$. cepaforma, fork 1 on forewing sessile. In male genitalia inferior appendages with length about equal to 3 times width, without a small spur on the basomesial angle; tergite $\mathrm{X}$ truncate apically.

Description. Spurs 1, 2, 2. Male forewing length 6.1-6.4 mm. Wings, broad and spotted, forewing (Fig. 88) with fork 1 sessile and posterior anastomosis stepped, with t1 more distal than $\mathrm{t} 3$ which is more distal than $\mathrm{t} 2$. Genitalia, Figs 89, 90. Segment IX widest midlaterally, preanal appendages large, rounded to broadly conical in dorsal view, in contact in midline, but not fused. Segment $\mathrm{X}$ broad, apically truncate, without medial process. Inferior appendages clasper-shaped, widely separated at bases, curving outwards beyond a mesial angle bearing a cluster of short stout setae. Phallus very short.
Distribution. Northern NT and northern Qld (Fig. 128).

\section{Species of the longiterga-group}

Oecetis digitata sp. nov.

Figures 91-93, 129

Material examined. Holotype, male, NT, Jim Jim Waterhole, Kakadu National Park, 5 Sepember 1979, J. Blyth (NMV T-18522).

Paratypes. NT: 7 males, 3 females, Muirella Park, 12 Oct 1972, E.F. Riek (ANIC); male, $12^{\circ} 06$ 'S $133^{\circ} 04^{\prime} \mathrm{E}, 19 \mathrm{~km}$ E by S of Mt Borrodaile, 5-6 Jun 1973, J.C. Cardale (ANIC); male, Jim Jim Creek, 19 km WSW of Mt Cahill, $12^{\circ} 5^{\prime} \mathrm{S} 132^{\circ} 33^{\prime} \mathrm{E}, 17$ Jun 1973, J. Cardale (ANIC); 1 male, 1 female, Gulungul Billabong, East Jabiru, 23 Feb 1988, P. Dostine (NTM); 1 male, $12^{\circ} 38^{\prime} \mathrm{S} 132^{\circ} 53^{\prime} \mathrm{E}$, Gulungul Billabong, East Jabiru, 20 May 1989, A. Wells and P. Suter (NTM); 1 male, ARRS, South Alligator River at Gimbat OSS Station, $13^{\circ} 34.3^{\prime} \mathrm{S}$ $132^{\circ} 36.7^{\prime} \mathrm{E}, 24$ May 1988, A. Wells and P. Suter (NTM); 3 males, ARRS, Kambolgie Creek, $13^{\circ} 28.9^{\prime} \mathrm{S} 132^{\circ} 22.0^{\prime} \mathrm{E}, 25$ May 1988, A. Wells and P. Suter (ANIC); 1 male, ARRS, East Alligator River at Cahills Crossing, 27 May 1988, A. Wells and P. Suter (NTM); 2 males, SAR site 1, 30 Sep 1988, P. Dostine (NTM); 5 males, $12^{\circ} 48^{\prime}$ S $132^{\circ} 49^{\prime} \mathrm{E}$, Baroalba Springs, 25 Apr 1991, Wells and Webber (NMV); 1 male, $12^{\circ} 42^{\prime} \mathrm{S} 132^{\circ} 57^{\prime} \mathrm{E}$, Kakadu National Park, Magela Creek, OSS Site 009, 8 Jun 1991, Wells and Webber (NTM); 1 male, $12^{\circ} 48^{\prime} \mathrm{S}$ $132^{\circ} 49^{\prime} \mathrm{E}$, Little Baroalba Creek, 10 Jul 1991, Wells and Webber (NTM); 5 males, female, Alligator River, Two Mile Hole, $12^{\circ} 42^{\prime} \mathrm{S}$ $132^{\circ} 09^{\prime} \mathrm{E}, 5$ Aug 1996, I Edwards (NMV).

Other material.WA: Kimberley, Four Mile Creek, 2 Feb 1979, J.E. Bishop (ANIC) (slide); male, female, $14^{\circ} 25^{\prime} \mathrm{S} 126^{\circ} 38^{\prime} \mathrm{E}$, CALM site 13/H $12 \mathrm{~km} \mathrm{~S}$ of Kalumburu Mission, 7-11 Jun 1988, T.A. Weir (ANIC); 5 males, female, NT, Alligator River Two Mile Hole, $12^{\circ} 42^{\prime} \mathrm{S}$ $132^{\circ} 09^{\prime} E, 5$ Aug 1996, I. Edwards, NMV. Qld: female, Palmer River, 20 Jun 1971, E.F. Riek (ANIC); male, $15^{\circ} 41^{\prime}$ S $145^{\circ} 12^{\prime}$ E, Annan River, $3 \mathrm{~km} \mathrm{~W}$ by S Black Mountain, 17 Sep 1980, J.C. Cardale (ANIC); male, 4 females, $15^{\circ} 25^{\prime} \mathrm{S} 141^{\circ} 53^{\prime} \mathrm{E}$, Hann River, $7 \mathrm{~km}$ NW by W Laura, 27 Jun 1986, J.C. Cardale (ANIC). NT: male, $12^{\circ} 57^{\prime}$ S 132 $33^{\circ} \mathrm{E}$, Jim Jim Creek, $19 \mathrm{~km}$ WSW of Mt Cahill, 17 Jun 1973, J.C. Cardale, ANIC; female, Howard Creek, $3 \mathrm{~km}$ E of Howard Springs, $12^{\circ} 27.5^{\prime} \mathrm{S}$ $131^{\circ} 3.1^{\prime} \mathrm{E}, 17$ Aug 1979, J. Blyth (NMV); 1 female, Magela Creek at Ranger pipe outlet, 20 May 1988, P. Suter and A. Wells (NTM); female, Magela Creek at Ranger Pipe Outlet, Suter and Wells, 23 May 1988 (NMV).

Diagnosis. Forewing length less than 4 times width, veins sclerotised, appear very prominent,footstalk absent on fork 1; an unusual forward bulge present at base of vein $\mathrm{Cu} 1 \mathrm{a}$. In male genitalia, inferior appendages with mesial margin irregular, not smoothly curved; phallus smoothly arched, length about 4 times width.

Description. Spurs 1, 2, 2. Male forewing length 6.6-8.1 mm. Wings strongly sclerotised with veins dark, hair short; in forewing (Fig. 91) fork 1 sessile, anterior anastomosis with t1 and $\mathrm{t} 2$ almost linear, and well distad of $\mathrm{t} 3$, a forwardly directed bulge on Cu1a. Male genitalia, Figs 92, 93. Segment IX almost of uniform length on all sides, but excavated deeply midventrally; preanal appendages slender, elongate. Segment X elongate in lateral view, slightly swollen towards base. Inferior appendages in ventral view with small inner lobe at about half length. Phallus,curved, slender with length about 4 times width. 

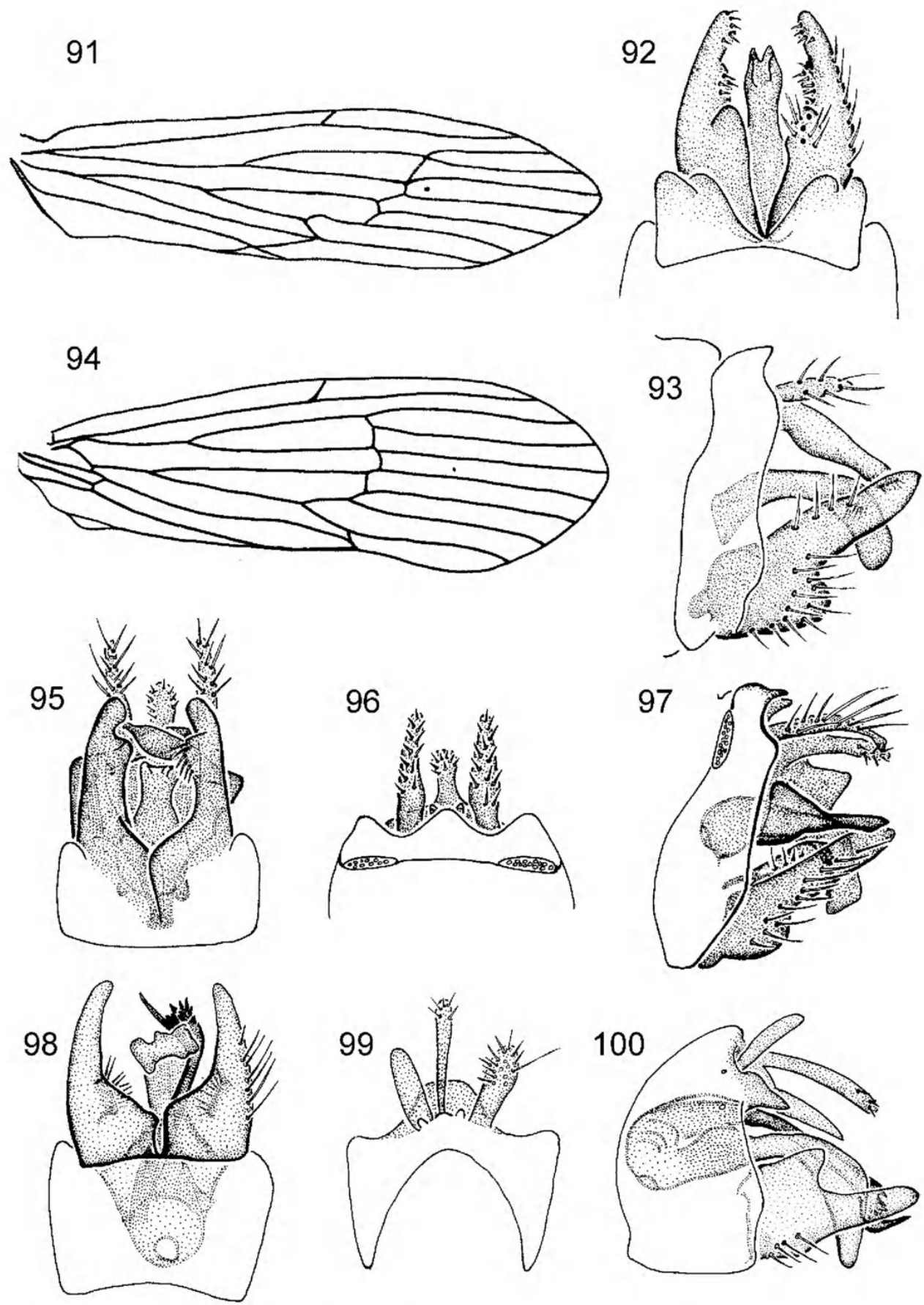

Figures 91-93, Oecetis digitata sp. nov.: 91, forewing; 92, 93, male genitalia, ventral and lateral views.

Figure 94, $O$. crosslandi sp. nov., forewing.

Figures 95-97, $O$. ancala sp. nov., male genitalia, ventral, dorsal and lateral views.

Figures 98-100, O. crosslandi sp. nov., male genitalia, ventral, dorsal and lateral views.

Distribution. Qld, NT, Kimberley Region of northern WA (Fig. 129).

Remarks. Several of the New Guinean Oecetis species resemble $O$. digitata in having broad wings with bold or prominent venation, and may be allied to this species. However, none has $\mathrm{Cu} 1 \mathrm{a}$ as in $O$. digitata and $O$. ancala sp. nov.

Etymology. Latin, digitata - having fingers, for the finger-like appearance of the male genitalia in lateral view.
Oecetis ancala sp. nov.

Figures 95-97, 130

Material examined. Holotype, male, SE Qld, Bulimba Creek, nr Brisbane Site R1, near Kimmax Street riffle, 23 Oct 1979 (NMV T-18523).

Paratypes. Qld: 3 males, Camp Mountain, 31 Mar 1967, N. Dobrotworsky (NMV); 2 males, female, Coondoo Creek, $30 \mathrm{~km} \mathrm{NE}$ of Gympie, Toolara State Forest, 28 Oct 1980, A. Neboiss (NMV); 3 males, female, Cooloola National Park, Freshwater Lake, 27 Nov 1985, D. Bickel and G. Cassis (NMV). 
Other material. WA: male, $\mathrm{N}$ end of Lake Argyle nr Kununurra, 6 Feb 1977, M.S. and B. Moulds (NMV); 7 males, female, Geikie Gorge, $18^{\circ} 06$ 'S $125^{\circ} 42^{\prime} \mathrm{E}, 5$ Oct 1996, I. Edwards (NMV). NT: 2 males, 2 females, Nourlangie Creek, $6 \mathrm{~km} \mathrm{E}$ of Mt Cahill, $12^{\circ} 52^{\prime} \mathrm{S} 132^{\circ} 46^{\prime} \mathrm{E}$, 18 Nov 1972, J.C. Cardale (ANIC); male, Katherine River Gorge National Park, 13 Aug 1979, J. Blyth (NMV); male, 2 females, Adelaide River, 15 km E of Stuart Highway, 15 Aug 1979, J. Blyth (NMV); male, Devil Devil Creek, $70 \mathrm{~km}$ SW of Daly River Mission, 23 Aug 1979, J. Blyth (NMV); 2 males, 2 females, $12^{\circ} 52^{\prime} \mathrm{S} 132^{\circ} 46^{\prime} \mathrm{E}$, Nourlangie Creek, $6 \mathrm{~km}$ E of Mt Cahill, 18 Nov 1972, J.C. Cardale (ANIC); male, ARRS, SAR at Gimbat OSS Stn, $13^{\circ} 34.3^{\prime} \mathrm{S} 132^{\circ} 36.7^{\prime} \mathrm{E}$, Wells and Suter, 24 May 1988 (NTM); 3 males, ARRS, Kambolgie Creek, $13^{\circ} 28.9^{\prime} \mathrm{S} 132^{\circ} 22.0^{\prime} \mathrm{E}, 25$ May 1988 , Wells and Suter (NTM); male, $12^{\circ} 36^{\prime} \mathrm{S} 132^{\circ} 53^{\prime} \mathrm{E}$, ARRS, Gulungul Creek, Inlet to Gulungul Billabong, 20 Apr 1989, Wells and Suter (NTM); 2 males, SAR Site 1, 30 Sep 1988, P. Dostine (NTM); male, 3 females, $12^{\circ} 42^{\prime} \mathrm{S} 132^{\circ} 57^{\prime} \mathrm{E}$, Kakadu National Park, Magela Creek, OSS Site 009, 15 Feb 1991, Wells (NTM); male, $12^{\circ} 42^{\prime} \mathrm{S} 132^{\circ} 57^{\prime} \mathrm{E}$, Kakadu National Park, Magela Creek, OSS Site 009, 8 Jul 1991, Wells and Webber (NTM). Qld: males, female, Cape York Peninsula, Pascoe River crossing (to Iron Range), 4 Oct 2002, G. Theischinger (ANIC); Cape York Peninsula, Dulhunty River crossing at Telegraph rd, 7 Oct 2002, G. Theischinger (ANIC). NSW: Barrington Tops, Barrington Tops Country Retreat, Dam, 22 Dec 2000, A. Wells (ANIC). Vic: male, Tyers River, LRES, 24 Feb 1974, Site 22 (NMV) (slide); male, female, Yarra River, below Upper Yarra Dam, 28 Feb 1976, A. Neboiss (NMV); male, female, Yarra River, Diamond Creek junction, 14 Mar 1976, A. Neboiss (NMV).

Diagnosis. Forewing as for $O$. digitata. In male genitalia, paired, sharply angled, sclerotised processes ventral to tergite $\mathrm{X}$, in ventral view appearing to be lateral to the phallus.

Description. Spurs 1, 2, 2. Male forewing length 7.9-9.4 mm. Wings, broad: forewing with fork 1 sessile, veins prominent; posterior anastomosis almost linear, oblique, marked by dark membrane forming a line across wing; Cula with a proximally directed bulge. Male genitalia, Figs 95-97. Segment IX narrow, preanal appendages discrete, slender, elongate, apices obliquely truncate in lateral view. Tergite $X$ slender, setose. Inferior appendages stoutly clasper-shaped in ventral view, a subapical notch mesially, in lateral view swollen basoventrally, then rod-shaped to rounded apex. Phallus long for a laustra-group species, arched ventrally. A pair of slender processes occur ventral to tergite $X$, appearing to be lateral to phallus in ventral view, sharply angled inwards at about half their length (ankle-shaped), in lateral view broad-based, tapered and slender distally.

Distribution. Northern WA, northern NT, south-eastern Qld, eastern NSW and south-central Vic (Fig. 130).

Remarks. The homologies of the unusual lateral processes are obscure, being impossible to determine from the prepared slides. In lateral view they seem to be associated in some way with tergite $X$, although in ventral view they appear to be closely associated with the phallus. If they are derived from the phallotheca, then this species should probably be placed in the complexa-group in the Australian fauna, but for the present they are dealt with as part of the laustra-group. Only few specimens have been collected at any one time, which suggests that the species may be far more widespread, but not often collected. This is consistent with the very curious distribution.
Etymology. Latin, ancala - a bent arm, descriptive of the structures lateral to the phallus.

\section{Oecetis crosslandi sp. nov.}

Figures 94, 98-100, 131

Material examined. Holotype male, Qld, Gunshot Creek at Telegraph Crossing, $11^{\circ} 44^{\prime} \mathrm{S} 142^{\circ} 29^{\prime} \mathrm{E}, 4-5 \mathrm{Apr} 1992$, M. Crossland (ANIC). Paratypes. 2 males, Qld: Heathlands, $11^{\circ} 45^{\prime} \mathrm{S} 142^{\circ} 35^{\prime} \mathrm{E}$, T. Weir (ANIC).

Diagnosis. Forewing broad, length about 3 times width; fork 2 sessile and wing veins strongly pronounced, but without bulge in vein Cula. In male genitalia a single heavily sclerotised dorsal paramere with a group of teeth and spikes subapically.

Description. Wings broad, veins pronounced; forewing (Fig. 94) apex rounded, fork 1 sessile, Cula almost straight. Male forewing, $5.3 \mathrm{~mm}$. In male genitalia (Figs 98-100), abdominal segment IX ventrally about 3 times middorsal length; preanal appendages elongate, length about 4 times width, apically rounded. Tergite $\mathrm{X}$ comprising a slender, elongate median lobe dorsal to a short rounded membranous plate. Inferior appendages broad-based, in ventral view sharply constricted on mesial margin, tapered to narrow apices, in lateral view with a short dorsal lobe. Phallus slender, downcurved in distal third, laterally on right, an elongate heavily sclerotised paramere with a subapical twist below a cluster of teeth and spikes.

\section{Distribution. Northern Cape York, Qld (Fig. 131).}

Remarks. One can only speculate on which features of $O$. digitata, $O$. ancala and $O$. crosslandi are homoplasious. I have assumed here, tentatively, that the synapomorphy for the group is the unusual form of the wing, which is shared by the New Guinean $O$. longiterga and at least one other New Guinean species (see Chen, 1992). However, Oecetis longiterga has a pair of internal parameres in the phallus, which feature could otherwise place it in the $O$. pechana-group; $O$. ancala and the New Guinea species of Chen's unpublished work have paired external parameres, somewhat similar to the arrangement in the O. complexa-group species (Wells, 2000); and $O$. digitata has the phallus simple, without parameres, which is characteristic of the $O$. laustra-group.

Etymology. Named for Michael Crossland.

\section{Acknowledgements}

My thanks to all who collected and provided specimens on which this study is based, and to the Museum Victoria and Museums and Art Galleries of the Northern Territory for making available the material in their collections. The Natural History Museum, London, through Dr R. Vane Wright, gave permission to reproduce figures from Mosely and Kimmins (1953). CSIRO Publishing is acknowledged for permission to use figures from the Australian Journal of Zoology and the Australian Journal of Marine and Freshwater Research. Museum Victoria is thanked for allowing use of figures from Memoirs of the National Museum of Victoria. CSIRO Entomology kindly provided laboratory facilities for this work. 

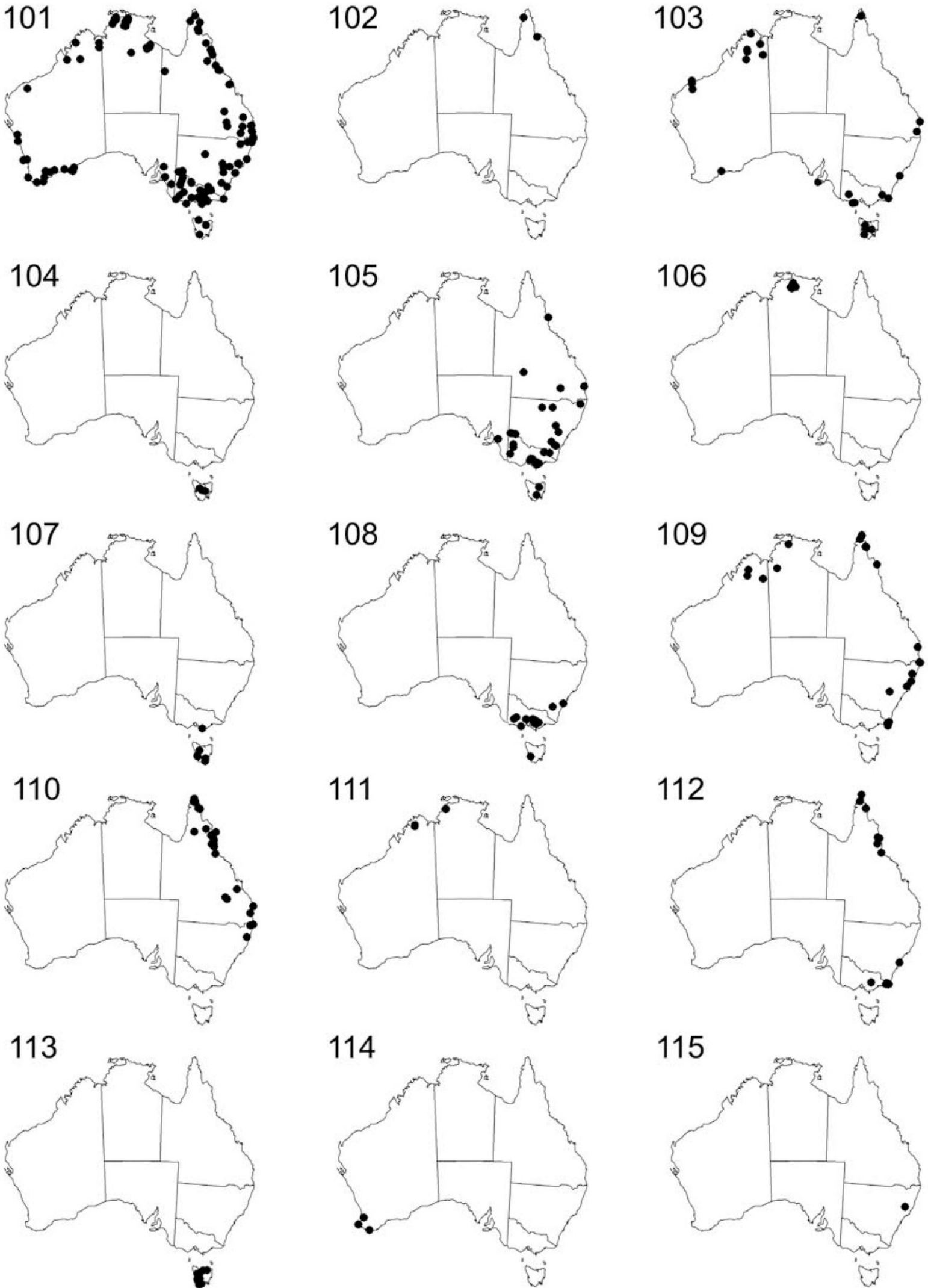

Figures 101-115, distribution of species within Australia:

101, Oecetis laustra Mosely; 102, O. pseudolaustra sp. nov.; 103, O. atarpa Mosely; 104, O. scirpicula Neboiss; 105, O. inscripta Kimmins; 106, O. brevidentata sp. nov.; 107, O. asmanista Mosely; 108, O. minasata Mosely; 109, O. aeoloptera Kimmins; 110, O. multipunctata Ulmer; 111, O. cracenta sp. nov.; 112, O. parka Mosely; 113, O. arcada Mosely; 114, O. cymula Neboiss; 115, O. paracymula, sp. nov. 

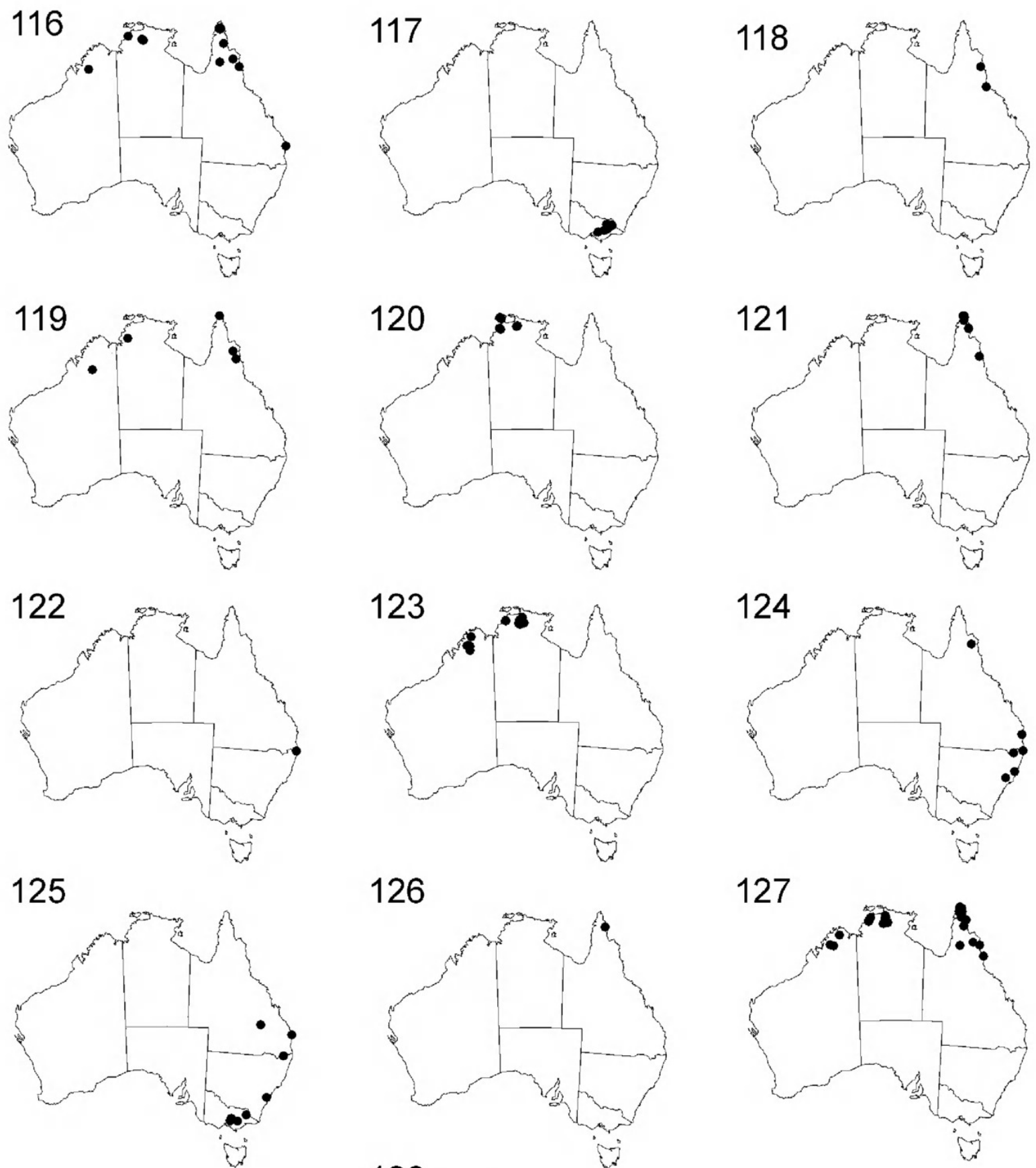

126
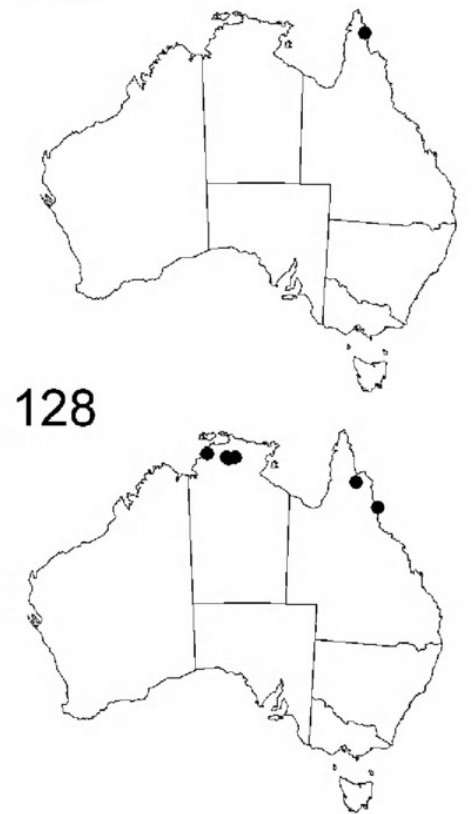

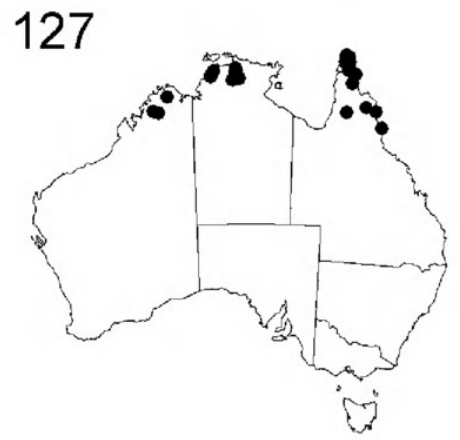

Figures 116-128, distribution of species within Australia:

116, Oecetis spicata sp. nov.; 117, O. crena sp. nov.; 118, O. quadrata sp. nov.; 119, O. dilata sp. nov.; 120, O. koobarra sp. nov.;

121, O. falcata sp. nov.; 122, O. terania sp. nov.; 123, O. papposa sp. nov.; 124, O. curta sp. nov.; 125, O. aduncata sp. nov.;

126, O. ornata Kimmins; 127, O. cepaforma sp. nov.; 128, O. dostinei sp. nov. 

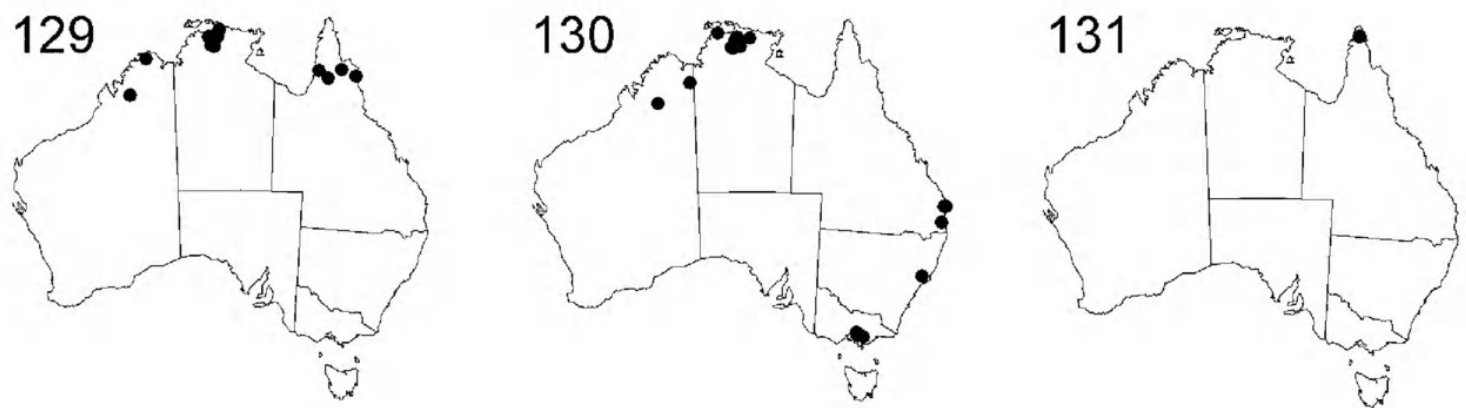

Figures 129-131, distribution of species within Australia:129, O. digitata sp. nov., 130, O. ancala sp. nov.; 131, O. crosslandi sp. nov.

My colleagues at the Australian Biological Resources Study are acknowledged for advice, particularly on handling of graphics, and for help in the use of the mapping programme, MapInfo, used to produce the maps. Brigitte Kuhlmayr's graphics skill improved some of the scanned images of published figures.

\section{References}

Chen, Y.E. 1992. Revision of the Oecetis (Trichoptera: Leptoceridae) of the World. Unpublished PhD Thesis, Clemson University, South Carolina, USA.

Floyd, M.A. 1995. Larvae of the caddisfly genus Oecetis (Trichoptera: Leptoceridae) in North America. Bulletin of the Ohio Biological Survey 10(3): i-viii 1-85.

Kimmins, D.E. 1962. Miss L. E. Cheeseman's expeditions to New Guinea. Trichoptera. Bulletin of the British Museum of Natural History (Entomology) 11: 99-187.

Mosely, M.E., and Kimmins, D.E. 1953. The Trichoptera (caddis-flies) of Australia and New Zealand. British Museum (Natural History): London. $550 \mathrm{pp}$.

Neboiss, A. 1977. A taxonomic and zoogeographic study of Tasmanian caddis-flies (Insecta: Trichoptera). Memoirs of the National Museum of Victoria 38: 1-208.

Neboiss, A. 1982. The caddis-flies (Trichoptera) of south-western Australia. Australian Journal of Zoology 30: 271-325.

Neboiss, A. 1986. Atlas of Trichoptera of the SW Pacific - Australian Region. Dr W. Junk Publishers : Dordrecht/Boston/Lancaster. 286 pp.

Neboiss, A. 1989. The Oecetis reticulata species-group from the South-West Pacific area (Trichoptera: Leptoceridae). Bijdragen tot de Dierkunde 59(4): 191-202.
Ruiter, D.E. 2000. Generic key to the adult ocellate Limnephiloidea of the Western Hemisphere (Insecta: Trichoptera). Ohio Biological Survey Miscellaneous Contributions 5. (Ohio Biological Survey: Columbus).

Schmid, F. 1980. Les insectes et arachnides du Canada, Partie 7, Genera des Trichoptères du Canada et des Etats adjacent. Agriculture Canada Publication 1692: 1-296.

Schmid, F. 1987. Considerations diverses sur quelques genres leptocerins (Trichoptera, Leptoceridae). Bulletin de l'Institut Royal des Sciences Naturelles de Belgique. Entomologie Vol. 57 Supplement: $1-147$.

St Clair, R.M. 1994. Some larval Leptoceridae (Trichoptera) from south-eastern Australia. Records of the Australian Museum 46: 171-226.

St Clair, R.M. 2000. Preliminary keys for the identification of Australian caddisfly larvae of the family Leptoceridae. Cooperative Research Centre for Freshwater Ecology, Identification Guide 27: $1-83$.

Ulmer, G. 1916. Results of Dr. E. Mjöberg's Swedish scientific expedition to Australia 1910-1913, 'Trichoptera'. Arkiv för Zoologi 10: $1-23$.

Wells, A. 1991. A guide to the caddisflies (Trichoptera) of the Alligator Rivers region, Northern Territory. Open File Record available from Supervising Scientist for the Alligator Rivers Region, GPO Box 461, Darwin, NT. 105 pp.

Wells, A. 2000. New Australian species of Oecetis allied to O. complexa Kimmins (Trichoptera: Leptoceridae). Memoirs of Museum Victoria 58(1): 77-88. 


\section{$2 \mathrm{BHL}$ Biodiversity Heritage Library}

Wells, Alice. 2004. "The long-horned caddisfly genus Oecetis (Trichoptera: Leptoceridae) in Australia: two new species groups and 17 new species." Memoirs of Museum Victoria 61, 85-110. https://doi.org/10.24199/j.mmv.2004.61.7.

View This Item Online: https://www.biodiversitylibrary.org/item/192562

DOI: https://doi.org/10.24199/j.mmv.2004.61.7

Permalink: https://www.biodiversitylibrary.org/partpdf/175700

\section{Holding Institution}

Museums Victoria

\section{Sponsored by}

Atlas of Living Australia

\section{Copyright \& Reuse}

Copyright Status: In copyright. Digitized with the permission of the rights holder.

Rights Holder: Museums Victoria

License: http://creativecommons.org/licenses/by-nc-sa/4.0/

Rights: https://biodiversitylibrary.org/permissions

This document was created from content at the Biodiversity Heritage Library, the world's largest open access digital library for biodiversity literature and archives. Visit BHL at https://www.biodiversitylibrary.org. 